\title{
Öğretmen Adayları ve Öğretmenlerin Öğretmenlik İle İlgili Metaforik Algılarının İncelenmesi
}

\author{
Fatih Çakmak*
}

Geliş Tarihi: 25/04/2020

Makale Kabul Tarihi: 01/08/2020

DOI: $10.35675 /$ befdergi.726660

$\ddot{O} z$

Bu araştırmanin temel amacı din ögrretiminde aday ögretmenler ile ögretmenlerin ögretmenlik ile ilgili algılarını metaforlar üzerinden belirlemektir. Araştırmada nitel araştırma desenlerinden fenemenolojik (olgubilimsel) araştırma deseni kullanılmıştır. Araştırmanın verileri katılımcıların, "öğretmen... gibidir/benzer; çünkü..." cümlesini tamamlamalar yoluyla toplanmıştır. Verilerin analizinde frekans, yüzde hesaplamaları ve içerik analizi çözümleme tekniği kullanılmıştır. Araştırma katılımcıları İslami İlimler Fakültesinden 255 aday ögretmen ve 80 din ögretimi alan dersi öğretmeninden oluşmaktadır. 255 aday ögretmen 108 adet metafor üretmiştir. İlk beş sırada yer alan metaforlar şunlardır: (1) Anne, (2) Güneş, (3) Bahçıvan, (4) Mum, (5) Aile, 9, \%3,52. Bu metaforlardan 11 farkl kavramsal kategori oluşturulmuştur. 80 ögretmen 52 farklı metafor üretmiştir. İlk beş sirada yer alan metaforlar şunlardır: (1) Bahçıvan, (2) Ăgaç, (3) Güneş, (4) Mum, (5) Fidan dikmek Bu metaforlardan 11 farklı kavramsal kategori oluşturulmuştur. Aday öğretmen ve öğretmenlerin öğretmenlik mesleği üzerine metaforik algıları birbirleri ile ilişkilendirilerek karşılaştırılmıştır.

Anahtar Kelimeler: Aday öğretmen, din öğretimi, metafor, öğretmen, ögretmenlik mesleği

\section{Examining The Metaphoric Perceptions About Teaching Of Candidate Teachers And Teachers İn Teaching Religion}

\begin{abstract}
The main purpose of this study is to determine the perceptions of prospective teachers and teachers about teaching in religious education through metaphors. In the research, phenomenological research pattern, which is one of the qualitative research patterns, is used. The data of the study are collected from the participants by completing these sentences: "The teacher is ... like/ similar, because..." Content analysis method, which is among frequency, percentage calculations and qualitative methods, has been used in analyzing the data. The research participants consisted of 255 candidate teachers from the Faculty of Islamic Sciences and 80 teachers from religion teaching. 255 prospective teachers produced 108 metaphors. The top five metaphors are: (1) Mother, (2) Sun, (3) Gardener, (4) Candle, (5) Family, 11 different conceptual categories have been created from these metaphors. 80 teachers produced 52 different metaphors. The top five metaphors are: (1) Gardener, (2) Tree, (3) Sun, (4) Candle,
\end{abstract}

\footnotetext{
* Afyon Kocatepe Üniversitesi, İslami İlimler Fakültesi, Felsefe ve Din Bilimleri Bölümü, Din Bilimleri Anabilim Dalı, Afyonkarahisar, Türkiye, fcakmak@aku.edu.tr, ORCID: 0000-00020333-3834
}

Kaynak Gösterme: Çakmak, F. (2021). Öğretmen adayları ve öğretmenlerin öğretmenlik ile ilgili metaforik algılarının incelenmesi. Bayburt Eğitim Fakültesi Dergisi, 16(31), 219-251. https://doi.org/10.35675/befdergi.726660. 
(5) Planting seedlings, 11 different conceptual categories have been created from these metaphors. The metaphorical perceptions of the prospective teachers and teachers on the teaching profession were compared with each other.

Keywords: Metaphor, prospective teacher, religious education, teacher, teaching profession

\section{Giriş}

İnsanlar varlık sahnesine çıktıkları andan itibaren farklı yollar kullanmak suretiyle duygu, düşünce, fikir vs. paylaşımında bulunmuşlardır. Yine insanlar bu süreçte bilmek, öğrenmek, öğretmek için de farklı yollar kullanmışlardır. İnsan üzerine çok fazla tanım yapılabilen bir varlıktır. Bunun sebebi insanın kendi varlık sahnesinde pek çok şey açısından hem özne hem de nesne olması olarak ifade edilebilir. Bu arada gerçeklik olarak ifade edebileceğimiz en temel hakikat ise insanın ögrenebilen bir varlık oluşudur. İnsan sahip olduğu özellikler ile (akıl ve irade gücü) öğrenebilen ve hatta öğrenmeye muhtaç olan bir varlıktır. Doğumundan ölümüne kadar bir yetişme ve değişme yaşayan ve sürekli öğrenen insan (Çakmak, 2013) için en önemli soru/sorun, bilginin ya da öğrendiklerinin değeri üzerine olmalıdır. Bu bağlamda bilginin değeri ile ilgili şu sorular ve cevapları üzerine düşünmek önem taşımaktadır:

Bilgi insana göre anlam kazanan bir değer mi, yoksa kimseye göre değişmeyen kesin bir değer midir?

Bireye verilen eğitim derinliğine anlamayı mı, yoksa yüzeysel bilgiler vermeyi mi esas almalıdır?

Bireye verilen eğitimde kişiler gelecekte kullanacağı bilgiyle mi doldurulmalı, yoksa kişilere bilgiyi kullanmanın yolları mı öğretilmelidir?

Eğitimin temelinde kişi bir bilgi deposu gibi görülerek sadece zihinsel gelişme mi olmalı, yoksa bireyler bireysel, sosyal, duygusal vs. yönler dikkate alınarak bütüncül bir gelişim mi önemsenmelidir? (Özden, 1998)

Eğitim, önceden saptanmış ilkelere göre, insanların davranışlarında belli gelişmeler sağlamaya yarayan planlı etkinlikler dizgesi (Demirel \& Kaya, 2007) olarak ifade edilmiştir. Öğrenme ise yaşantı ürünü olan ve nispeten kalıcı izli olan davranış değişikliği demektir (Ertürk, 1997). Buna göre eğitimin amacinın gerçekleşmiş olması aynı zamanda öğrenmenin gerçekleştiği anlamına gelmektedir. (Kesici, 2016). Genel anlamda öğrenme kavramı, var olan toplumsal duruma, kurallara ve kültürel gereklere ayak uydurma biçimidir (Kaya, 2012). Ancak bu öğrenmenin gelişi güzellikten kurtularak bir sisteme bağlaması gerekmektedir. Gerek bireye istenen şeyleri öğretme girişimleri, gerek bir ekonomi sağlama gayesiyle eğitim ve öğretimin planlı olması istenmiştir. Bu planlı öğrenme olayını gerçekleştirmek üzere, okul adı verilen kurumlar oluşturulmuştur (Nalçacı \& Bektaş, 2012). 
Öğretme en genel ifadeyle öğrenme işinin kılavuzlanması (Demirel, 2015) ve bir lider/öğretmen tarafından gerçekleştirilmesi işidir. Yani öğretme, öğrenmeyi sağlama, öğrenmiş olanın bir başkasının öğrenmesi için yapmış olduğu bilinçli ve kasıtlı etkinlikleri kapsayan, öğrenenin öğrenmesine rehberlik etme faaliyetidir (Senemoğlu, Gömleksiz \& Üstündağ 2001). Öğrenme ve öğretme faaliyetlerinin bütünü olarak, öğretim, bu faaliyetlerin okulda planlı ve programlı olarak gerçekleştirilmesidir. Yani eğitimin okulda planlı olarak bir süreç içerisinde yürütülen, kontrollü ve örgütlenmiş öğretme faaliyetleridir (Fidan, 1996; Erden, 1998). Okul denilen yer kimilerine göre bir örgüt, kimilerine göre bir işletme, kimilerine göre bir aile, kimilerine göre de bir insan topluluğu olarak tanımlanabilir. Bu bağlamda okul, her şeyden önce sosyal bir yaşam alanıdır (Şişman, 2016).

Öğretmen, öğrenmesi gereken ya da öğrenme ihtiyacında olan bireyin bu temel ihtiyacını karşılayan, öğrenme faaliyetine uzman olarak liderlik ve rehberlik eden kişidir. Bu bağlamda öğretmen, öğrenmeyi ilerletmek, geliştirmek, desteklemek amacıyla öğrencinin çevresinde uygun eğitim ortamları düzenlemekten sorumludur (Kesici, 2016). Öğretmenlik mesleği, 1973 tarihli 1739 sayılı Millî Eğitim Temel Kanununda şöyle tanımlanmaktadır: "Öğretmenlik, devletin eğitim, öğretim ve bununla ilgili öğretim görevlerini üzerine alan, özel bir ihtisas mesleğidir”. Aynı yasada "hangi kademede olursa olsun öğretmen adaylarının yükseköğretimden geçmeleri esastır ve öğretmenlik mesleğine hazırlık, genel kültür, özel alan eğitimi ve pedagojik formasyonla sağlanır" hükmüyle de öğretmen adaylarının yetişme ölçütleri ve dolayısıyla öğretmenlerin sahip olmaları gereken davranış kategorileri belirlenmiştir (Şahin, 2011). Öğretmenler öğretme/öğrenme faaliyetini kaliteli ve etkili bir şekilde gerçekleştirebilmek için farklı boyutlarda bazı niteliklere sahip olmalıdırlar. Öğretmenlerin etkili ve kaliteli bir öğretme gerçekleştirebilmeleri için sahip olmaları gereken bu boyutlar/nitelikler Şen ve Erişen (2002) tarafından etkili öğretmenlik özellikleri üzerine yapılan bir araştırmada şöylece ifade edilmiştir:

1. Öğretmenler; etkili öğretmenlik özelliklerinin "konu alanı bilgisi" boyutunda gerekli niteliklere sahip olmalıdırlar.

2. Öğretmenler "genel kültür" boyutunda gerekli niteliklere sahip olmalıdırlar.

3. Öğretmenler "plân yapma ve derse hazırlık" boyutunda gerekli niteliklere sahip olmalıdırlar.

4. Öğretmenler "öğretme-öğrenme stratejileri” boyutunda gerekli niteliklere sahip olmalıdırlar.

5. Öğretmenler "öğretim araç ve gereçleri” boyutunda gerekli niteliklere sahip olmalidirlar.

6. Öğretmenler "iletişim" boyutunda gerekli niteliklere sahip olmalıdırlar.

7. Öğretmenler "ssnıf yönetimi”" boyutunda gerekli niteliklere sahip olmalıdırlar. 
8. Öğretmenler "ölçme ve değerlendirme" boyutunda gerekli niteliklere sahip olmalidirlar.

9. Öğretmenler "kişisel özellikler" boyutunda gerekli niteliklere sahip olmalıdırlar (Şen \& Erişen, 2002).

Bir yaşam alanı olan ve eğitim etkinliğinin gerçekleştiği örgüt olarak okullarda istenilen kalitede hizmet verilebilmesi/alınabilmesi için okullardaki insan gücünün geliştirmesi önemli bir ihtiyaçtır. Okullardaki etkinliğin lider/rehber gücü olarak öğretmenler bu gelişim için gerekli olan gereksinimleri hizmet öncesi anlamında mesleğe başlamadan önce ve hizmet içi anlamında meslek hayatı devam ederken alırlar. Öğretmenlik mesleğine hazırlık, genel kültür, özel alan bilgisi ve öğretmenlik meslek bilgisi ile sağlanır (Demirel, 1999). Öğretmenler sadece sınıf içinde öğreten değil aynı zamanda tüm yaşama yön veren gerçek bir lider/rehber olarak yetiştirilebilmelidirler. Bir ülkenin kalkınmasında, nitelikli insan gücünün yetiştirilmesinde, toplumdaki huzur ve sosyal barışın sağlanmasında, bireylerin sosyalleşmesi ve toplumsal hayata hazırlanmasında, toplumun kültür ve değerlerinin genç kuşaklara aktarılmasında öğretmenlerin başrolü oynamaları beklenmektedir (Özden, 1999). Aynı zamanda öğretmen, öğrenme öğretme süreçlerinin temel öğesi olarak öğrenciyle devamlı etkileşim halinde bulunan, eğitim programını uygulayan, eğitim ortamında istendik davranışları kazandıran, öğretimi yöneten ve hem öğretimin hem de öğrencinin değerlendirmesini yapan kişidir (Kılıç \& Saruhan, 2005). Öğretmenin niteliği ve yeterliliği eğitim öğretim faaliyetinin başarıya ulaşmasında en önemli faktördür (Büyükkaragöz, Muşta \& Yılmaz, 1998).

Ülkemizde din eğitimi ve öğretimi ile ilgili tartışmalar her zaman yapılagelmiştir. $\mathrm{Bu}$ tartışmaların ekseni iki temel görüş üzerinden ilerlemiştir: Birincisi dinin bu toplumun mayasını oluşturan tarihsel bir gerçeklik olduğu mutlaka bireylere din eğitimi verilmesi gerekliliği; ikincisi laik bir toplumda din eğitimi ve öğretiminin olup olmayacağı ya da din eğitimi ve öğretiminin devlet eliyle zorunlu olarak verilip verilenmeyeceği konularıdır. Bu noktada çok derin açıklamalar gerektirecek bu konuya girmenin bu araştırmanın konusunu aşacağını belirterek kısaca şunu belirtmekte fayda vardır. Din bireylerin ve toplumların hayatında mevcut olduğu sürece, o dinin inanma biçiminin, uygulanma şeklinin, yaşam tarzının vs. insanlara belli bir sistematik içerisinde, belli ilke ve esaslar çerçevesinde kontrollü bir şekilde verilmesi de bir zorunluluk olmaktadır. Zira insanlar inanma eğilimli doğalarındaki temel ihtiyacı karşılamak isteyeceklerdir. Bunula birlikte bu tartışmaların genelde bilimsel zeminden uzak olduğunu da belirtmekte fayda vardır. Eğitim sistemi ile ilgili tartışmaların bilimsel bir temele dayanması gerekliliğini Varış şu şekilde ifade eder: "Eğitim uygulamalı bir bilim alanıdır. Bu bakımdan yenileşme çabalarını kâğıt üzerinde özenerek çizilmiş yapı değişiklikleriyle, yapılan konuşma ve tartışmalarla veya herkesin kendi tecrübe dağarcığından çıkararak en iyi niyetlerle ortaya attı̆̆ 1 önerilerle gerçekleşeceği düşünülmemelidir. Her şeyden önce, memleketimizde eğitimin toplumsal ve bireysel temellerini araştırarak, eğitimin sistematik teorisini 
dile getirmek ve eğitim politikasını ve amaçlarını bu teoriye göre düzenlemek gerekmektedir. Bireyin topluma yapıcı bir şekilde aktif uyumunu sağlayacak, davranışların gelişmesine yön çizecek olan amaçların, bilimsel bir temele oturması önem taşır. Eğitim amaçlarının gerçekleştirilmesinde uygulanacak muhtevanın seçimi ve düzeni bu alanda akademik çaba gerektirmektedir" (Varış, 1994).

Din eğitimi, "bireyin dini davranışlarında kendi yaşantıları yoluyla ve kasıttı olarak istendik değişme meydana getirme denemeleri süreci" (Tosun, 2001) olarak tanımlanmaktadır. Din eğitimi ile din öğretimi kavramları ülkemizde genelde birlikte ya da aynı anlamda kullanılırlar. Ayrıca din öğretimini tanımlamak gerekirse, bu sürecin okulda planlı ve programlı olarak gerçekleştirilen kısmıdır. Yani din eğitiminin okulda planlı olarak bir süreç içerisinde yürütülen, kontrollü ve örgütlenmiş öğretme faaliyetlerine din öğretimi diyebiliriz. Bu bağlamda ülkemizde Din Kültürü ve Ahlak Bilgisi dersi zorunlu dersler arasındadır. Bununla birlikte öğrenciler seçmeli ders olarak Kur'an-1 Kerim, Hz. Muhammed'in Hayatı ve Temel Dinî Bilgiler derslerini de alabilmektedir. Din öğretimi alanı öğretmeni ise, bu alanda öğrenmesi gereken ya da öğrenme ihtiyacında olan bireyin bu temel ihtiyacını karşılayan, öğrenme faaliyetine uzman olarak liderlik ve rehberlik eden kişidir. Yukarıda etkili ve kaliteli öğretmenlik bilgisi ve becerisi ile ilgili olarak yapılan tüm açıklamalar din öğretimi alan derslerinde öğrenene liderlik ve rehberlik yapan tüm öğretmenler için de geçerlidir. Hatta bu ülkede kaliteli ve nitelikli bir din öğretimine olan ihtiyacın diğer pek çok alandan daha da önemli olduğu son dönemin yaşanan olumsuzlukları düşünüldüğünde açıkça ortadadır. Bu açıdan din öğretimi ve din öğretimini gerçekleştiren öğretmenler hizmet öncesinde kaliteli ve nitelikli yetişmiş olmalı, aynı zamanda görev süreci devam ederken bu süreç devam etmelidir. Bununla birlikte din öğretimi alan öğretmenleri ülkenin kalkınmasında, nitelikli insan gücünün yetiştirilmesinde, toplumdaki huzur ve sosyal barışın sağlanmasında, bireylerin sosyalleşmesi ve toplumsal hayata hazırlanmasında, toplumun kültür ve değerlerinin genç kuşaklara aktarılmasında ne kadar önemli bir sorumluluk üstlendiklerinin farkında olmalıdırlar. Ayrıca din öğretimi alanı öğretmenleri öğrenciyle devamlı etkileşim halinde bulunan, eğitim programını uygulayan, eğitim ortamında istendik davranışları kazandıran, öğretimi yöneten ve hem öğretimin hem de öğrencinin değerlendirmesini yapan kişiler olarak da hem görev ve sorumluluklarını bilmeli hem de kaliteli uygulayıcılar olmalıdırlar. Bu açılardan düşünüldüğünde din öğretimi alan öğretmenlerinin önemi ortadadır. İşte bu bağlamda araştırmamızın temel problemi şudur:

Din öğretimi alan dersleri aday öğretmenleri ile öğretmenlerin "öğretmenlik" ile ilgili metaforik algıları nasıldır? Bu temel problem çerçevesinde araştırmamızın alt problemleri de şunlardır:

1. Aday öğretmenler öğretmenlik mesleğini hangi metaforlarla açılamaktadır?

2. Aday öğretmenler tarafindan ortaya konan metaforlar ortak özellikleri bakımından hangi kavramsal kategoriler altında toplanabilir? 
3. Din öğretimi alan öğretmenleri öğretmenlik mesleğini hangi metaforlarla açıklamaktadır?

4. Öğretmenler tarafından ortaya konan metaforlar ortak özellikleri bakımından hangi kavramsal kategoriler altında toplanabilir?

5. Aday öğretmenlerin öğretmenlik ile ilgili metaforları ile öğretmenlerin öğretmenlik ile ilgili metaforlar arasında nasıl bir ilişski vardır?

\section{Yöntem}

\section{Araştırma Deseni}

Din öğretiminde aday öğretmen ve öğretmenlerin öğretmenlik ile ilgili algılarının metaforlar üzerinden belirlenmeye çalışılan bu araştırmada nitel araştırma desenlerinden fenemenolojik (olgubilimsel) araştırma deseni kullanılmıştır. Fenomenolojik araştırma, araştırmacının katılımcılar tarafından tanımlanmış şekliyle bir fenomenle ilgili bireylerin yaşanılan deneyimleri betimlediği, kaynağını, felsefe ve psikolojiden alan bir araştırma desenidir (Creswell, 2017). Bu desende bireylerin farkında olduğu fakat derinlemesine ve ayrıntılı bir anlayışa sahip olmadığı olaylar, algılar, deneyimler, kavramlar ve durumlar gibi çeşitli biçimlerde karşımıza çıkan olgulara odaklanılmaktadır. (Yıldırım \& Şimşek, 2013). Fenomenolojik araştırmada betimlemeler söz konusu fenomen ile ilgili çeşitli deneyimlere sahip bireylerin deneyimlerinin özüne ulaşılması ile sonuçlanır (Creswell, 2017). Bireylerin araştırılacak olan fenomenle (öğrenme, öğretme gibi) ilgili olarak ortaya attıkları tanımlar kategorilere ayrılır. Tanımların kategorilere ayrılması bireylerin ne düşündüklerini açıkça ortaya koyar (Çekmez, Yıldız \& Bütüner, 2012). Bu nedenle bu araştırmada aday öğretmen ve öğretmenlerin öğretmenlik ile ilgili algılarını tespit ederek değerlendirebilmek için bu yöntem seçilmiştir.

\section{Katılımcilar}

Araştırmanın çalışma grubunu Afyon Kocatepe Üniversitesi İslami İlimler Fakültesinde 2019-2020 öğretim yılında öğrenim görmekte olan aday öğretmenler ve din öğretimi alan dersleri öğretmenleri oluşturmaktadır. Araştırma katılımcıları İslami İlimler Fakültesinden 70 adet 2. sinıf, 100 adet 3. sinif ve 85 adet 4. sinıf öğrencisi aday öğretmeni ve 80 adet din öğretimi alan dersi öğretmeninden oluşmaktadır.

\section{Verilerin Toplanması ve Analizi}

Araştırmada veri toplama aracı olarak metaforlar kullanılmıştır. Metaforlar yoluyla veri toplamak nitel araştırmalarda hem kolay bir veri toplama aracıdır hem de bu sayede toplanan verilerin analiz edilmesi kolaydır. Aynı zamanda metaforlar aracılı̆̆ ile elde edilen veriler sözcüklerden ibaret olduğu için benzerlikler ve farklılıklar 
kullanılmak suretiyle elde edilen verileri kategorize etmek de kolay olmaktadır (Yıldırım \& Şimşek, 2013). Metaforlar aracılığı ile araştırma grubundan çalışılan olgu/durum hakkında bir betimleme yapmaları istenmiş ve bu betimleme aracıllğ̆ ile katılımcıların olgu/durum ile ilgili algıları ortaya konmaya çalışılmıştır. Bu amaçla araştırmanın çalışma grubunu oluşturan aday öğretmen ve öğretmenlere "öğretmenlik" kavramına ilişkin sahip oldukları metaforları ortaya çıkarmak amacıyla "öğretmen...gibidir / benzer; çünkü..." yazılı olan formlar verilerek tamamlamaları istenmiştir. Araştırmada öğretmen kavramı ile ilgili metaforları belirlerken "gibi" kavramı metaforun konusu ile metaforun kaynağı arasındaki bağ ifade etmesi için kullanılırken, "çünkü" kavramı kullanılan metaforlar için bir gerekçe sunulmasını sağlamaktadır (Küçüktepe \& Gürültü, 2014).

$\mathrm{Bu}$ çalışmada elde edilen veriler frekans, yüzde hesaplamaları ve içerik analizi yöntemi kullanılarak çözümlenmiştir. İçerik analizinde birbirine benzeyen veriler, belirli kavramlar ve temalar çerçevesinde bir araya getirilir ve okuyucunun anlayabileceği bir biçimde organize edilerek yorumlanır. (Yıldırım \& Şimşek, 2013). İçerik analizi yapılırken elde edilen veriler bazı aşamalardan geçirilir. Bu aşamalar şunlardır:

1. Kodlama ve ayıklama aşaması; katılımcıların formlarda belirttikleri metaforlar ve sebep cümleleri alfabetik olarak sıralanır. $\mathrm{Bu}$ aşamada birden fazla metafor belirtilen ya da metafor verilip sebebi belirtilmeyen formlar elenir.

2. Örnek metafor imgesi derleme aşaması; katılımcıların ürettikleri metaforlar, 'metaforun konusu', 'kaynağı', kaynak ve konu arasındaki ilişki bakımından incelenir. $\mathrm{Bu}$ aşamada metafor kaynağı ile konusu arasında mantıklı ilişki kurulamayan formlar elenir.

3. Kategori geliştirme aşaması; Katılımcılar tarafindan oluşturulan metaforlar 'kaynak ve konu arasındaki ilişki' açısından incelenerek kategoriler geliştirilir (Egüz \& Öntaş, 2018).

\section{Metafor}

Metafor (métaphore) kelimesi; meta sonra-ile-öte gibi anlamlara gelen ve fora (phora) sözü aktarmak, yüklemek, taşımak gibi anlamlar taşıyan iki parçadan oluşur (Levine, 2005). İngilizce bir kelime olan "metafor" (metaphor), Türkçe'de "benzetme, eğretileme", eski Türkçede "mecaz", Arapça'da "teşbih/istiare" kelimeleriyle karşılanmaktadır (Aydın, 2006). Sözlükte mecaz anlamında metafor; "bir ilgi veya benzetme sonucu gerçek anlamından başka anlamda kullanılan söz; bir kelimeyi veya kavramı kabul edilenin dışında başka anlamlara gelecek biçimde kullanma" olarak ifade edilmiştir. (TDK, 2020). Buna göre metaforlar, insanların belli bir olguyu başka bir olguyla görmesini sağlayan zihinsel modellerdir (Saban, 2008). Başka bir ifadeyle metaforlar, bir kavram, kelime, terim ya da olgunun daha güzel ve iyi anlaşılmak/anlatılmak için, başka bir anlamda olan bir sözcükle ilgi kurularak 
benzetme yoluyla kullanılmasıdır (Aydın, 2006). Metafor sadece bir benzetme ya da söz sanatı değil, aynı zamanda dünyayı görme ve anlama biçimidir (Morgan, 1998). $\mathrm{Bu}$ anlamda metaforlar kullanarak bazı olay, olgu ya da kavramları başka bir anlamda olan bir sözcükle ilgi kurarak daha iyi anlayabiliriz.

Çağdaş teoriye göre Lakoff ve Johnson (2010) tarafından metaforların özellikleri şöyle ifade edilmiştir:

1. Metafor kelimelerin değil, kavramların niteliğidir.

2. Metaforun işlevi sadece sanatsal veya estetik kaygılarla ifadelerin retorik etkisini artırmak değil; aynı zamanda belirli kavramları daha iyi anlamayı sağlamaktır.

3. Metafor çoğunlukla benzerliğe dayanmaz; hatta bu benzerlikleri yaratmaktadır.

4. Metafor özel bir yeteneği olmayan sıradan insanlarca gündelik hayatta büyük bir zihin faaliyeti gerektirmeksizin kullanılır.

5. Metafor linguistik bir süs, gereksiz bir dekor değil, insani düşüncenin ve akıl yürütmenin ayrilmaz bir unsurudur.

İnsanlar farkında olarak ya da olmayarak tarihin derinliklerinden itibaren daha iyi anlatmak ya da anlaşmak için metafor/mecaz/benzetme yapmışlardır. Bununla ilgili olarak edebiyattan, felsefeden vs. örnekler ortaya koymak mümkündür. Biz burada araştırmamızın bağlamı çerçevesinde bu örnekleri Kutsak Kitap'tan vermek istiyoruz. İnsan ile Yaratıcısı arasındaki iletişimin temel biçimi olan vahyin kaynaklığında, bu iletişimin son şeklini ortaya koyan ve değişmemesi bir zorunluluk olan Kuran'da Rabbi insana bazı olay, olgu ya da kavramları daha iyi anlatabilmek için metafor/mecaz/benzetme kullanmıştır. Zira İlah’tan insana doğru gerçekleşen bu iletişimde kendisine anlatılanları en açık şekliyle anlamak zorunluluğu olan insanın daha iyi anlamasını sağlamak maksadıyla Yaratıcı, gerektiğinde her türlü dilsel ve düşünsel formu kullanmak suretiyle onun anlamasını sağlamak istemiştir. Şöyle ki, “konuşma sezdirimi” kuramının sahibi dilbilimci H. Paul Grice’e göre sözlü ve yazılı iletişimde dikkate alınması gereken dört temel ilke vardır:

1. Kemiyyet; gerekenin eksiksiz söylenmesi, ne çok ne de az söylenmemesidir.

2. Keyfiyet; inanılan, tecrübe edilen, delil getirebilen şeyin söylenmesi, samimi olunmasidir.

3. İrtibat; mevzu ile ilişkili şeylerin söylenmesi, söylenen şeylerin makama uygun olmasidir.

4. Açıklık; söylenilen şeylerle maksadın kolayca anlaşılması, muhatabın zihninin karıştırılmamasıdır (Alan, 1994). 
Benzetme yapılan metaforda üç temel öge bulunur. Bunlar; benzeyen, benzetilen ve benzetilene ait özellik ya da benzetme yönüdür (Saban, 2004). Şimdi Kuran'dan metafor örneklerine geçebiliriz:

“ Allah katında İsa'nın misali Âdem 'in misali gibidir ki onu topraktan yarattı...” (Âl-i İmrân, 3/59). Metafor ögeleri açısından ayet incelendiğinde; Hz. İsa benzeyen, Hz. Âdem kendisine benzetilen, topraktan yaratılma da benzetme yönüdür.

"Sen dağlarl görürsün de onları yerinde durur sanırsın. Oysa onlar bulutların yürümesi gibi yürümektedirler"," (Neml, 27/88). Ayet incelendiğinde; dağlar benzeyen, bulutlar kendisine benzetilen, hareketli olma benzetme yönüdür.

“Tevrât'la yükümlü tutulup da onunla amel etmeyenlerin durumu, ciltlerce kitap taşıyan eşeğin durumu gibidir...” (Cuma, 62/5). Ayet incelendiğinde asıl Tevrat ile hükmetmeyen, İlahi ilke ve esaslara kendilerini kapatan Yahudiler benzeyen, ciltlerce kitap taşıyan eşek benzetilen, gereksiz ağır yükler taşıma ve bu gereksiz ağır yüklerin altında ezilme, bunun fayda sağlamaması durumu benzetme yönüdür.

"Sanki etrafa yayılmış çekirge sürüsü gibi bakışları perişan (utançtan yere bakar) bir halde kabirlerden çıkarlar” (Kamer, 54/7). Ayet incelendiğinde kabirlerinden çıkan, diriltilen insanlar benzeyen, etrafa yayılmış çekirge sürüsü kendisine benzetilen, çokluk da benzetme yönüdür.

"Inkâr edenlere gelince, onların amelleri, düz arazideki serap gibidir ki susayan onu su zanneder...” (Nûr, 24/39). Ayet incelendiğinde inkâr edenlerin işleri benzeyen, düz arazideki serap benzetilen, inkârcıların işlerinin boşa çıkması, bir fayda sağalamaması da benzetme yönüdür. Benzer daha pek çok ayetten örnek verilebilir. Burada bilinmesi dereken şudur ki Yaratıcı insana anlatmak istediği ve daha çok insanın anlamakta güçlük çekebileceği olay, olgu ya da kavramı insanların bilebilecekleri, kendi yaşamlarından benzerleri ile ilişkilendirerek/benzeterek anlatmış ve insandan bunları daha iyi anlamalarını istemiştir.

Bireyler gerek iş gerekse sosyal yaşamlarında ifade gücünü arttırmak amacıyla sıklıkla başvurdukları metaforlar (Aykaç \& Çelik, 2014) son yıllarda sosyal bilimlerde de önemli bir veri elde etme aracı olarak kullanılmaktadır (Yıldırım \& Şimşek, 2013). Ayrıca son yıllarda bireylerin karmaşık, soyut bir olguyu anlama ve anlamlandırmada kendilerine başvurabilecekleri zihinsel bir araç olarak metaforlar (Yob, 2003), eğitim alanında da kullanılmaktadır. Metaforların eğitim alanında kullanılmasının bazı faydaları vardır. Şöyle ki; metafor kullanımı derse olan motivasyonu artırır, bilginin kalıcılığını sağlar, duygusal gelişimi iyileştirebilir, sezgileri geliştirebilir, sınıf/ders korkusunu ve isteksizliğini ortadan kaldırır, yaratıcılığı geliştirir ve hayal gücünü arttırır (Arslan \& Bayrakçı, 2006)

Alanyazında öğretmen, öğrenci, öğrenme, öğretme, okul, program vb. kavramlar üzerine gerçekleştirilmiş metaforik çalışmalar mevcuttur (Baker, 1991; Balc1, 1999; Martinez, Sauleda \& Huber, 2001; Saban, 2004; Cerit, 2008; Nalçacı \& Bektaş, 2012; 
Tortop, 2013; Karateke, 2019). Benzer bir araştırma Saban (2004) tarafından 151 sınıf öğretmeni adayı ile gerçekleştirilmiştir. $\mathrm{Bu}$ araştırmada katılımcılar tarafından üretilen 54 metafor, 6 farklı kategoride toplanmıştır. Benzer bir araştırma Yılmaz, Göçen ve Yılmaz (2013) tarafından 370 öğretmen adayının katılımıyla gerçekleştirilmiştir. Bu araştırmada katılımcılar; Sınıf öğretmenliği, Sosyal bilgiler öğretmenliği, Fen bilgisi öğretmenliği, Okul öncesi öğretmenliği ve İlköğretim matematik öğretmenliği bölümlerinden seçilmiştir. Araştırmada katılımcılar tarafından üretilen 141 metafor 7 farklı kategoride toplanmıştır. Benzer bir farklı araştırma Koç (2014) tarafından 168 Sınıf öğretmeni adayı katılımcı ile gerçekleştirilmiştir. $\mathrm{Bu}$ araştırmada katılımcılar tarafından üretilen 53 metafor, 8 farklı kategoride toplanmıştır. Literatürde benzer şekilde Nalçacı ve Bektaş (2012) tarafından yapılan farklı bir araştırmada öğretmen adaylarının okul kavramına ilişkin algıları metaforlar üzerinden tespit edilmeye çalışılmıştır. Araştırmada 83 metafor üretilmiş ve 11 farklı kategori altında toplanmıştır (Nalçacı \& Bektaş, 2012). Bir başka araştırmada Tortop (2013) öğretmen adaylarının üniversite hocası hakkındaki algılarını metaforlar üzerinden tespit etmiştir. Araştırmada 16 kategoride, 183 farklı metafor belirlenmiştir (Tortop, 2013). Bu araştırma ise, din öğretimi aday öğretmenleri ile öğretmenlerin öğretmenlik mesleği ile ilgili algılarını metaforlar üzerinden belirlemek, öğretmen adayları ile öğretmenlerin öğretmenlik algılarını ilişkilendirmek istemekte ve bu şekilde alana katkı sunmayı amaçlamaktadır.

\section{Bulgular ve Yorum}

\section{Öğretmen Adayları İle İlgili Bulgular}

\section{Araştırmaya katılan aday öğretmenler ile ilgili tanımlayıcı bilgiler}

Araştırmaya katılan aday öğretmen ile ilgili tanımlayıcı bilgiler tablo 1'de verilmiştir.

Tablo 1.

Araştırmaya Katılan Aday Öğretmenlere Ait Tanımlayıcı Bilgiler

\begin{tabular}{lll}
\hline Değişken & Kategori & $\mathbf{N}$ \\
\hline \multirow{2}{*}{ Cinsiyet } & K1z & 185 \\
& Erkek & 70 \\
\hline \multirow{3}{*}{ Sinıf } & 2. Sinıf & 70 \\
& 3. Sinıf & 100 \\
& 4. Sinıf & 85 \\
\hline TOPLAM & & $\mathbf{2 5 5}$ \\
\hline
\end{tabular}


Tablo 1'e göre araştırmaya 255 aday öğretmen katılmıştır. Bu katılımcıların 185 'i bayan (\%72,5), 70’i erkektir (\%27,5). Ayrıca katılımcıların 70’i 2. Sinıf $(\% 27,5)$, 100’ü 3. Sinıf (\%39,2), 85’i de 4. Sinıf $(\% 33,3)$ öğrencisidir.

\section{Aday öğretmenler tarafindan üretilen metaforlar}

Araştırmaya katılan İslami İlimler Fakültesi öğretmen adaylarının “Öğretmen” kavramına ilişkin geliştirdikleri metaforlar ve onları temsil eden öğrenci sayısı ve yüzdesi (alfabetik sıraya göre) Tablo 2'de verilmiştir:

Tablo 2.

Aday Öğretmenlerin Öğretmenlik Mesleğine İlişkin Ürettikleri Metaforların Frekans Ve Yüzde Dă̆llımları

\begin{tabular}{|c|c|c|c|c|c|c|c|}
\hline Metafor & Metafor Adı & $\mathbf{N}$ & $\%$ & 26 & Çiftçi & 5 & 1,96 \\
\hline Sirası & & & & 27 & Çinicilik & 1 & 0,39 \\
\hline 1 & Ağaç & 5 & 1,96 & 28 & Çömlek ustası & 1 & 0,39 \\
\hline 2 & Akıl oyunu & 1 & 0,39 & 29 & Dikiş makinası & 1 & 0,39 \\
\hline 3 & Âlim & 1 & 0,39 & 30 & Doktor & 2 & 0,78 \\
\hline 4 & Anahtarlık & 1 & 0,39 & 31 & Dokuma halı & 1 & 0,39 \\
\hline 5 & Anne & 21 & 8,23 & 32 & Duvar & 1 & 0,39 \\
\hline \multirow[t]{2}{*}{6} & Anti-virüs & 1 & 0,39 & 33 & Ekin & 2 & 0,78 \\
\hline & sistemi & & & 34 & Elbise dikmek & 1 & 0,39 \\
\hline 7 & Aile & 9 & 3,52 & 35 & Elek & 1 & 0,39 \\
\hline \multirow[t]{2}{*}{8} & Ar1 & 1 & 0,39 & 36 & $\mathrm{Ev}$ & 1 & 0,39 \\
\hline & Aşçılık & 1 & 0,39 & 37 & Fabrika & 2 & 0,78 \\
\hline 10 & Ateş & 2 & 0,78 & 38 & Fener & 6 & 2,35 \\
\hline 11 & Avukat & 1 & 0,39 & 39 & Fesleğen & 1 & 0,39 \\
\hline 12 & Ay & 5 & 1,96 & 40 & Filozof & 2 & 0,78 \\
\hline 13 & Ayna & 3 & 1,17 & 41 & Gelecek & 2 & 0,78 \\
\hline 14 & Bahçıvan & 14 & 5,49 & 42 & Gökyüzü & 2 & 0,78 \\
\hline 15 & Balıkçı & 1 & 0,39 & 43 & Gökkuşağ1 & 1 & 0,39 \\
\hline 16 & Bardak & 1 & 0,39 & 44 & Gönle dokunmak & 1 & 0,39 \\
\hline 17 & Bayrak yarışı & 1 & 0,39 & 45 & Gübre & 2 & 0,78 \\
\hline 18 & Beyincik & 1 & 0,39 & 46 & Gül & 1 & 0,39 \\
\hline 19 & 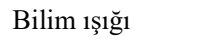 & 1 & 0,39 & 47 & Güneş & 17 & 6,66 \\
\hline \multirow[t]{2}{*}{20} & Bina & 1 & 0,39 & 48 & Hayat & 4 & 1,56 \\
\hline & kolonu/kirişi & & & 49 & Hediye paketi & 1 & 0,39 \\
\hline 21 & Bulmaca çözmek & 1 & 0,39 & 50 & Hemşire & 1 & 0,39 \\
\hline 22 & Cemre & 2 & 0,78 & 51 & Iş̧ı & 7 & 2,74 \\
\hline 23 & Cihat & 1 & 0,39 & 52 & İlkbahar & 1 & 0,39 \\
\hline 24 & Çiçek & 1 & 0,39 & 53 & İkindi güneşi & 1 & 0,39 \\
\hline \multirow[t]{2}{*}{25} & Çiçek & 1 & 0,39 & 54 & İsviçre çakısı & 1 & 0,39 \\
\hline & yetiștirmek & & & 55 & Kahramanlık & 1 & 0,39 \\
\hline
\end{tabular}

Journal of Bayburt Education Faculty, Year: ... Volume: ... Number: ... 


\begin{tabular}{|c|c|c|c|c|c|c|c|}
\hline 56 & Kalp & 1 & 0,39 & 84 & Pusula & 3 & 1,17 \\
\hline 57 & Kalorifer kazanı & 1 & 0,39 & 85 & Rehber & 5 & 1,96 \\
\hline 58 & Kandil & 2 & 0,78 & 86 & Rock & 1 & 0,39 \\
\hline 59 & Kırmızı kalem & 1 & 0,39 & & sanatçı1sı & & \\
\hline 60 & Kivilcim & 1 & 0,39 & 87 & Rüzgâr & 2 & 0,78 \\
\hline 61 & Kitap & 3 & 1,17 & 88 & Sanatkâr & 1 & 0,39 \\
\hline 62 & Kitap kapağ 1 & 1 & 0,39 & 89 & Sayg1 & 1 & 0,39 \\
\hline 63 & Kitap önsözü & 1 & 0,39 & 90 & $\mathrm{Su}$ & 7 & 2,74 \\
\hline \multirow[t]{2}{*}{64} & Kitle inşa/imha & 1 & 0,39 & 91 & Sudoku bulmaca & 1 & 0,39 \\
\hline & silahı & & & 92 & Şifalı ağaç & 1 & 0,39 \\
\hline 65 & Komedyen & 1 & 0,39 & 93 & Şiir & 1 & 0,39 \\
\hline 66 & Koyun & 1 & 0,39 & 94 & Tarla ırgatı & 1 & 0,39 \\
\hline 67 & Kutup yıldızı & 2 & 0,78 & 95 & Tohum & 1 & 0,39 \\
\hline 68 & Lamba & 2 & 0,78 & 96 & Tomurcuk & 1 & 0,39 \\
\hline 69 & Lens & 1 & 0,39 & 97 & Toprak & 5 & 1,96 \\
\hline 70 & Lokomotif & 1 & 0,39 & 98 & Topuklu & 1 & 0,39 \\
\hline 71 & Marangoz & 6 & 2,35 & & ayakkabı & & \\
\hline 72 & Matruşka & 1 & 0,39 & 99 & Umut & 1 & 0,39 \\
\hline 73 & Meyve ağacı & 1 & 0,39 & 100 & Usta & 4 & 1,56 \\
\hline 74 & Mum & 13 & 5,09 & 101 & Yağmur & 4 & 1,56 \\
\hline 75 & Nakkaş & 1 & 0,39 & 102 & Yağmur bulutu & 1 & 0,39 \\
\hline 76 & Navigasyon & 1 & 0,39 & 103 & Yapboz parçası & 1 & 0,39 \\
\hline 77 & Nehir & 1 & 0,39 & 104 & Yazar & 1 & 0,39 \\
\hline 78 & Orkestra şefi & 1 & 0,39 & 105 & Y1ldız & 5 & 1,96 \\
\hline 79 & Papatya & 1 & 0,39 & 106 & Yüklem & 1 & 0,39 \\
\hline 80 & Pazarcı & 1 & 0,39 & 107 & Yürüyen kitap & 2 & 0,78 \\
\hline 81 & Pergel & 1 & 0,39 & 108 & Yol & 1 & 0,39 \\
\hline 82 & Peygamberlik & 4 & 1,56 & & & & \\
\hline 83 & Piyanist & 1 & 0,39 & TOPLAM & & 255 & 100 \\
\hline
\end{tabular}

Tablo 2 incelendiğinde araştırma 255 adet aday öğretmen ile gerçekleştirilmiştir. Katılımcıların ürettikleri metaforlar ile ilgili bulguları aşağıdaki gibi özetleyebiliriz:

1. 255 aday öğretmen öğretmenlik mesleği ile ilgili olarak 108 adet metafor geliştirmiştir.

2. Aday öğretmenlerin ürettikleri 108 adet metaforun 72 'si sadece bir aday öğretmen tarafından temsil edilmektedir. $\mathrm{Bu}$ da yaklaşık olarak katılımcıların \% 67'sine karşılık gelmektedir. Buna göre araştırmaya katılan aday öğretmenlerin metafor üretmedeki düşünce zenginliklerini ortaya koymaktadır. Geriye kalan yaklaşık \% 33'e yakın aday öğretmen 36 adet metafor üretmişlerdir. Başka bir ifadeyle 36 adet metafor 2 ila 21 aday öğretmen arasında değişen rakamlarda temsil edilmektedir. Metafor başına düşen aday öğretmen sayısı ise 2,36'dır. 
3. İlk beş sırada yer alan metaforlar şöyle belirlenmiştir: (1) Anne, 21 öğretmen adayı, \%8,23. (2) Güneş, 17, \%6,66. (3) Bahçıvan, 14, \%5,49. (4) Mum, 13, \%5,09. (5) Aile, 9, \%3,52.

4. 108 adet metaforun 42'si canlı varlıklarla, 66's1 cansız varlıklarla ilgilidir. 42 canlı varlıkla ilgili metaforun 10'u bitkilerle, 2'si hayvanlarla, 30'u da insan ile ilgilidir. 30 adet insan ile ilgili metaforun 26 tanesi mesleklerle ilgilidir. Yani 26 metaforda öğretmenlik mesleği başka bir meslek ile ilişkilendirilerek anlatılmaya çalışılmıştır. 66 adet cansız metaforun 52 tanesi somut varlıklarla, 14'ü soyut varlıklarla ilişkilidir.

\section{Aday öğretmenler tarafından üretilen metaforların ait oldukları kategoriler}

Aday öğretmenler tarafından üretilen metaforlar öğretmenlik mesleğine ilişkin sahip oldukları ortak özellikler bakımından analiz edilmiştir. Bu aşamada belirlenen 108 adet metaforun öğretmenlik olgusunu nasıl kavramsallaştırdığına bakılmıştır. Bu çerçevede aday öğretmenler tarafindan üretilen her metafor (1) metaforun konusu, (2) metaforun kaynağı ve (3) metaforun konusu ile kaynağı arasındaki ilişki bakımlarından analiz edilmiştir. Daha sonra her metaforun öğretmenliğe ilişkin sahip olduğu yaklaşım/bakış açısı belli bir tema ile ilişkilendirilerek (örneğin, " Bireysel gelişime katkı sağlayan olarak öğretmen”, vb.) toplam 11 farklı kavramsal kategori oluşturulmuştur. Bu kategoriler tablo 3 'te verilmiştir.

Tablo 3.

\section{Metaforların Kategorilere Dă̆ılımı}

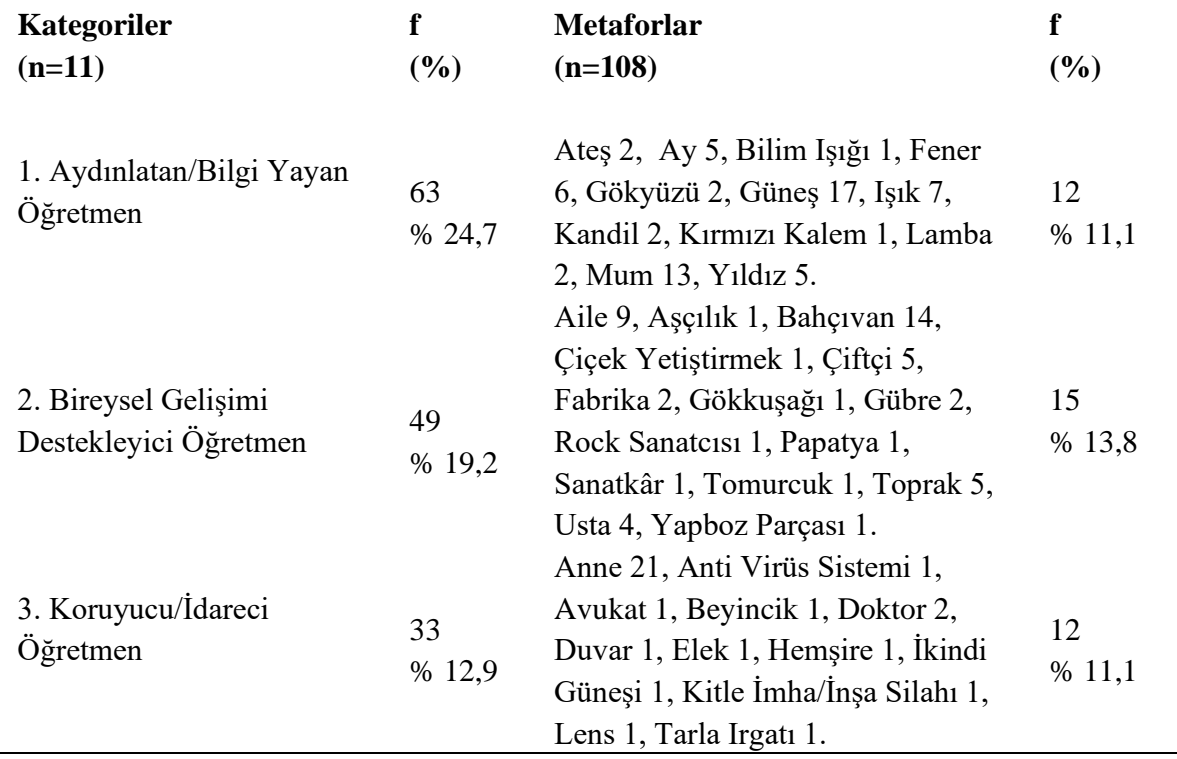




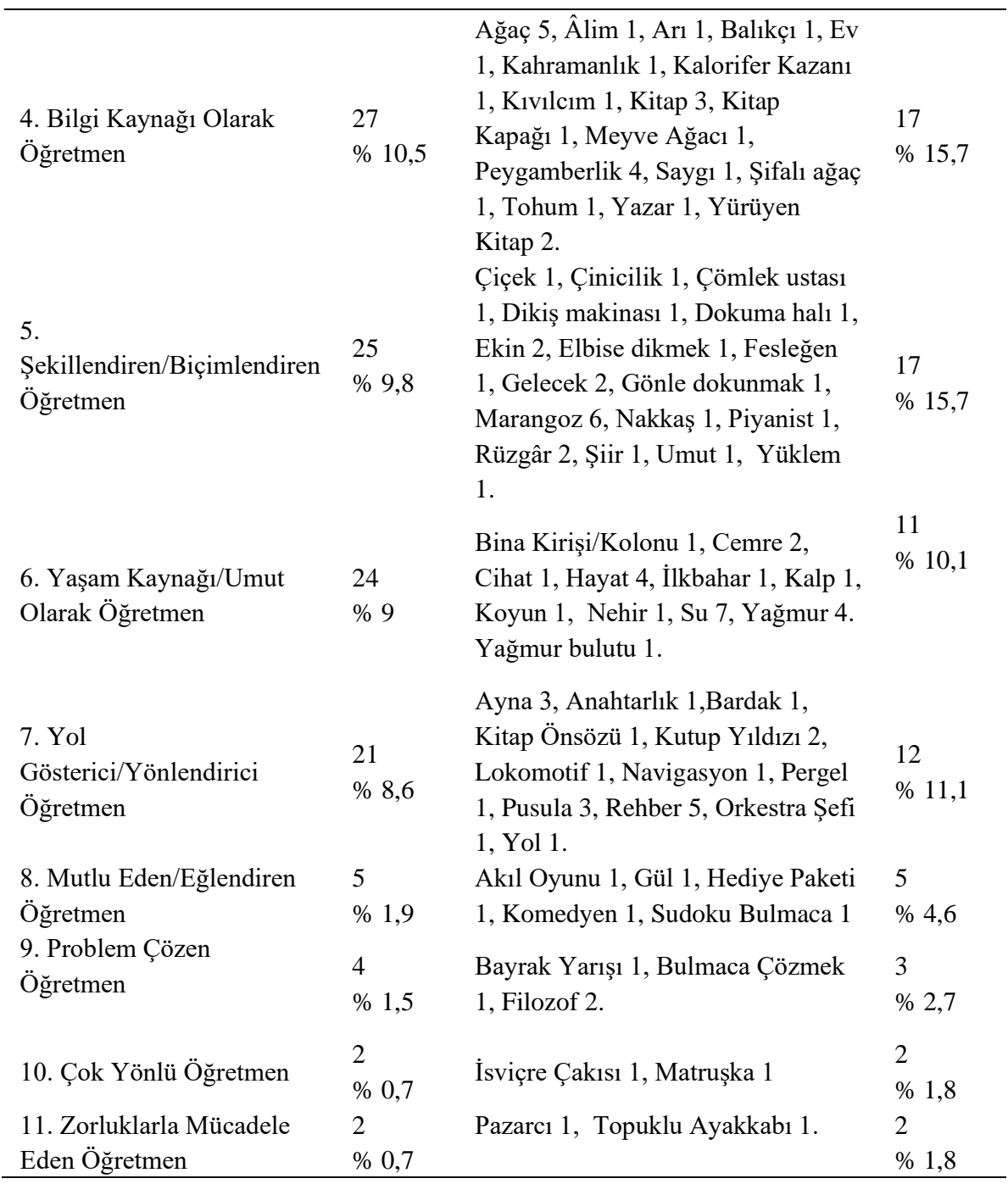

Kategori 1. Aydınlatan/Bilgi Yayan Öğretmen. Tablo 3 "aydınlatan/bilgi sağlayan öğretmen" kategorisini oluşturan metaforları ve her bir metaforu geliştiren aday öğretmen sayısını ve yüzdesini sunmaktadır. Buna göre kategori 63 aday öğretmen $(\% 24,7)$ ve 12 metafor $(\% 11,1)$ ile temsil edilmektedir. Bu kategorideki metaforların en önemlileri şunlardır: Güneş (17 öğretmen adayı, \% 6,6), mum (13, \% 5,), ş̧ı (7, $\% 2,7)$, fener $(6, \% 2,3)$ ve ay $(5, \% 1,9)$. Aşağıda, bu kategoride yer alan metaforlarla ilgili aday öğretmenlerin tanımlanmalarına ilişkin örnekler yer almaktadır.

Güneş 
Öğretmenlik mesleği güneşe benzer. Karanlıkta ve aydınlıkta her daim, her koşulda etrafina ışık saçandır yol gösterendir (4. Sınıf, Bayan).

Öğretmenlik mesleği güneşe benzer, sen öğrencilerine bilgi ve ahlak bakımından ışık oldukça onlar da parlar ve başkalarına ışık olur (4. Sınıf, bayan).

\section{Mum}

Öğretmenlik mesleği muma benzer. Çünkü kendisi yandıkça etrafina ışık verir, etrafinı aydınlatır (3. Sinıf, bayan).

Işık

Öğretmenlik mesleği ışık gibidir. Çünkü bilginin var olduğu her yer aydınlık iken cahilliğin var olduğu her yer karanliğa mahkûmdur. Öğretmenler de öğrencilerine yol gösteren, önünü aydınlatan ışıklardır (3. Sınıf, bayan).

\section{Fener}

Öğretmenlik mesleği deniz fenerine benzer. Nasıl ki zifiri karanlıkta yönünü bulmakta zorlanan gemilere yol göstericiyse denizdeki o fener; ögretmen de ögrencilerine öyle yol gösterir (4.sinıf, bayan).

Ay

Öğretmenlik mesleği aya benzer. Karanlıktaki geceyi bir tek o aydınlatır (2.sınıf, bayan).

Kategori 2. Bireysel Gelişimi Destekleyici Öğretmen. Tablo 3' e göre bu kategori 49 aday öğretmen $(\%$ 19,2) ve 15 metafor $(\%$ 13,8) ile temsil edilmektedir. Bu kategorideki metaforların en önemlileri şunlardır: Bahçıvan (14 öğretmen adayı, $\% 5,4)$ aile $(9, \% 3,5)$, çiftçi $(5, \% 1,9)$, toprak $(5, \% 1,9)$ usta $(4, \% 1,5)$. Aşağıda, bu kategoride yer alan metaforlarla ilgili aday öğretmenlerin tanımlanmalarına ilişkin örnekler yer almaktadır.

Bahçıvan

Öğretmenlik mesleği bir bahçıvana benzer. Çünkü bir bahçıvan bahçesindeki güllere çiçeklere ă̆açlara özenle bakıp onlarl en güzel hale getirir ve sonunda da dünyanın en güzel bahçesini meydana getirir. O bahçe bulunduğu yeri cennete çevirir. O bahçeyi gören herkes onu yetiştirene teşekkür eder. İşte ögretmende bir bahçıvandır. Öğrencilerine böyle sevgi ile bakar, büyütür ve korur. Bahçesi okul, çiçekleri ögrencileri, yürĕ̆i kova, suyu ise sevgisidir (3. Sinıf, bayan).

Aile

Öğretmenlik mesleği aile gibidir. Çünkü sadece alanıyla ilgili ĕgitimin dışında hayata dair dersler verir ögrencilerinin yanında olur onlarla ilgilenir ailenin nasıl 
çocuğunu yetiştirip kişiliği hayatını o yönde şekillendirdiği gibi öğretmenin yetiştirmesi de ögrencinin hayatını kişiliğini şekillendirir (2. Sınıf, bayan).

Çiftçi

Öğretmenlik mesleği çiftçiliğe benzer Çünkü ĕger çiftçi faydall verimli bir ürün elde etmek istiyorsa o mahsule gerekli ilgiyi göstermesi gerekiyor, ilacını gübresini suyunu vermesi gerekiyor. Öğretmen de aynı şeyi yapıyor, öğrenciye bilgiyi aşılamak için aynı derecede çabalıyor, gelecek nesil onların eseri oluyor yani ikisinde de ne ekersen onu biçersin (2. Sinıf, erkek).

\section{Toprak}

Öğretmenlik mesleği toprak gibidir/benzer. Çünkü nasıl ki toprak sürekli tüm canlılara fayda săglayacak mahsuller verirse, ögretmen de vatana, millete ve tüm canlı gruplarına hayır sağlayacak ögrenciler yetiştirmeye çalışır (2. Sınıf, erkek).

\section{Usta}

Ö̆̆retmenlik mesleği bir ustaya benzer. Çünkü tek amacı gittiği yoldan, aldı̆̆ bilgilerden ve tüm emeklerinden ögrencilerine armă̆an olarak birakmasıdır (2. Sinıf, bayan).

Kategori 3. Koruyucu/İdareci Öğretmen. Tablo 3' e göre bu kategori 33 aday öğretmen $(\% 12,9)$ ve 12 metafor $(\% 11,1)$ ile temsil edilmektedir. Bu kategorideki metaforların en önemlileri şunlardır: Anne (21 öğretmen adayı, \% 8,2), beyincik (1, $\% 0,3)$, doktor $(2, \% 0,7)$, duvar $(1, \% 0,3)$, anti virüs sistemi $(1, \% 0,3)$, lens $(1, \%$ $0,3)$. Aşağıda, bu kategoride yer alan metaforlarla ilgili aday öğretmenlerin tanımlanmalarına ilişkin örnekler yer almaktadır.

\section{Anne}

Öğretmenlik mesleği anneye benzer. Çünkü karşılık beklemeksizin şefkatle bakar, sever, sıkıntısı olduğunda dertlenir, elinden geleni yapar, örnek olur, eğitir, öğretir (4. Sinıf, bayan).

Öğretmenlik mesleği yüreklerimizi sevgisiyle sımsıcak yaparak şefkatiyle kalplerimizi saran anneler gibidir. Çünkü ögretmenler; konuşamayan bir çocuğun dahi umudu, sevginin azmin sabrın şefkatin gücüyle imkânsızlıkları başaran, her zaman yanımızda yıkılmayan bir kale gibi duran koruyucularımızdır (2. Sinıf, bayan).

Beyincik

Öğretmenlik mesleği vücuttaki beyincik gibidir/benzer. Çünkü vücudumuzda dengeyi sağlayan bir organ olduğu için ona zarar geldiğinde tüm sistem yerle bir olur. Aynı ögretmen de böyledir. O olmadı̆̆ında tüm dengemiz alt üst olur (4. Sınıf, bayan).

Doktor 
Öğretmenlik mesleği, aslında bir doktora benzer. Çünkü doktor hastasını tedavi ederken büyük bir titizlikle uğraşır onun hastalığına fayda verebilecek ilaçları ve gerekli cerrahi müdahaleleri yapar. Şayet yanlış bir müdahalede bulunursa bu hasta olan kişinin hayatını sonuna kadar etkileyebilmektedir. Öğretmenlik bu yüzden o meslekle çok yakından ilgilidir. Nitekim öğretmen olan kişi ilk olarak okula yeni başlayan çocuklardan tutun da son sınıfa kadar öğrencilerinin her konuda faydalı, etkili ve ileride kendisinin hayatını her alanda koruyacak bilgileri ve davranışları öğretmeye çalışır. Şayet yanlış müdahale yaparsa bu o çocuğun hayatını sonuna kadar etkileyebilmektedir. Doğru teşhis sağlam karakteri beraberinde getirir denebilir (3. Sınıf, erkek).

\section{Duvar}

Öğretmenlik mesleği, aslında bir duvar gibidir. Çünkü öğrenciler ne zaman boşluğa düşseler arkalarında o duvarı hissederler (2. Sınıf, erkek).

Anti virüs sistemi

Öğretmenlik mesleği, anti virüs sistemi gibidir. Çünkü tehlikeye açık dimă̆ları korur, onlara yanlışı ayırt edebilme, doğruyu görebilme yeteneği kazandırır (4. Sınıf, erkek).

Lens

Öğretmenlik lens gibidir. Çünkü insanları kötülükten korur, varliğında anlamazsın kıymetini yokluğunda anlarsın (4. Sınıf, bayan).

Kategori 4. Bilgi Kaynağ1 Olarak Öğretmen. Tablo 3' e göre bu kategori 27 aday öğretmen $(\% 10,5)$ ve 17 metafor $(\% 15,7)$ ile temsil edilmektedir. Bu kategorideki metaforların en önemlileri şunlardır: Ağaç (5 öğretmen adayı, \% 1,9), peygamberlik $(4, \% 1,5)$ kitap $(3, \% 1,1)$ yürüyen kitap $(2, \% 0,7)$, âlim $(1, \% 0,3)$, kıvılcım $(1, \%$ $0,3)$, Yazar 1, Aşağıda, bu kategoride yer alan metaforlarla ilgili aday öğretmenlerin tanımlanmalarına ilişkin örnekler yer almaktadır.

A ğaç

Öğretmenlik mesleği ağaç gibidir. Çünkü kökleri sağlam olduğu sürece (yani alan ve gelişim dönemlerini iyi bildiğinde) meyveleri de güzel olur, ögrencilerini en iyi şekilde bilgilendirir (4. Sinıf, bayan).

Peygamberlik

Öğretmenlik mesleği peygamberlik gibidir/benzer. Çünkü tüm peygamberler aynı zamanda bir öğretmendir. Hak ile batılın ne olduğunu öğretir (4. Sınıf, erkek).

Kitap

Öğretmenlik meslĕ̆i yazarın kendisi olduğu kitap gibidir. Çünkü öğretmen kendisindeki bilgileri kitabına yazdı̆̆ı şekliyle öğrenciye aktarır (2. Sınıf, bayan). 


\section{Yürüyen Kitap}

Öğretmenler yürüyen kitaplar gibidir. Çünkü nasll ki bilinmeyen konularda ilk çaremiz kitaplardan yardım almaktır, ögretmenlik de bilgi edinilmek istenen tüm konularda başvurulan bir meslektir.

Âlim

Öğretmen âlim gibidir. Çünkü öğrencisinin gözünde her şeyi bilen ve kendisine ögretendir (3. Sinıf, bayan).

Kivilcim

Öğretmenlik meslĕ̆i kıvılcım gibidir/benzer. Çünkü bilgi ya da öğrenilmesi gerekenler mevcuttur. Bunu ögrenciye işlemek asıl olan iştir. Bu öğretmenin emeği ile gerçekleşir. Öğretmen ögrenciye bu kıvllcımı hissettirip öğrenme isteğini içine işlerse o kıvılcımı çakmış olur (2. Sinıf, bayan).

Yazar

Öğretmenlik mesleği yazar gibidir/benzer. Çünkü en güzel eserler onların elinden geçer (4. Sınıf, erkek).

Kategori 5. Şekillendiren/Biçimlendiren Öğretmen. Tablo 3' e göre bu kategori 25 aday öğretmen $(\%, 9,8)$ ve 17 metafor $(\%$ 14,8) ile temsil edilmektedir. $\mathrm{Bu}$ kategorideki metaforların en önemlileri şunlardır: Marangoz (6 öğretmen adayı, \% $2,3)$, rüzgâr $(2, \% 0,7)$, gelecek $(2, \% 0,7)$ ekin $(2, \% 0,7)$, çinicilik $(1, \% 0,7)$, fesleğen $1, \% 0,7)$. Aşağıda, bu kategoride yer alan metaforlarla ilgili aday öğretmenlerin tanımlanmalarına ilişkin örnekler yer almaktadır.

\section{Marangoz}

Öğretmenlik mesleği marangozluk gibidir. Ĕğer marangoz işlenmemiş basit bir odun parçasında ustalığını gösterirse bir şaheser meydana getirir, Öğretmenler de tertemiz saf duygularla okula gelen ögrencileri eğiterek onlarda düzgün bir şahsiyet meydana getirir ( 3. Sinıf, erkek).

\section{Rüzgâr}

Öğretmen rüzgâr gibidir. Çünkü rüzgâr taşları senelerce şekillendirmeye çalışır bu kısa vadede çok belli olmaz ama sonrasında bir milletin peri bacası gibi bir kültür mirası olduğu görülür. Öğretmenler de senelerce incitmeden milim milim şekillendirmeye çalışır, sonrasında işe yaradığını görebilir (4.sınıf, bayan).

Gelecek

Öğretmenlik mesleği geleceğe benzer. Çünkü bir öğrencinin şekil alıp, geleceğinin belirlenmesi ögretmen sayesinde olur (3. Sinıf, bayan). 


\section{Ekin}

Öğretmenlik mesleği ekin gibidir/benzer. Çünkü ögrretmenler de bir çocuğun şekillenmesinde ve onun ilerideki başarılarında büyük etkiye sahiptir (3. Sınıf, bayan).

Çinicilik

Öğretmenlik mesleği çinicilik gibidir/benzer. Çünkü çinici toprağa şekil veren, onu pişiren, faydall bir eşya haline getirendir. Öğretmen de öğrenciyi pişiren, ona şekil veren, onu topluma faydalı hale getirendir (2. Sinıf, erkek).

Fesleğen

Öğretmenlik mesleği fesleğene benzer. Çünkü nasıl ki fesleğene dokununca mis kokular saçar, ögretmen de öğrencinin kalbine dokunarak onların içinde gizli kalmış güzellikleri ortaya çıkartır (2. Sınıf, bayan).

Kategori 6. Yaşam Kaynağ1/Umut Olarak Öğretmen. Tablo 3' e göre bu kategori 23 aday öğretmen (\%9) ve 10 metafor $(\% 9,2)$ ile temsil edilmektedir. Bu kategorideki metaforların en önemlileri şunlardır: Su (7 öğretmen adayı, \% 2,7), yağmur (4, \% 1,5) hayat $(4, \% 1,5)$, cemre $(2, \% 0,7)$, nehir $(1, \% 0,3)$. Aşağıda, bu kategoride yer alan metaforlarla ilgili aday öğretmenlerin tanımlanmalarına ilişkin örnekler yer almaktadir.

\section{$\mathrm{Su}$}

Öğretmenlik mesleği bir fidana su vermek gibidir. Çünkü bir fidan için su ne ise, bir öğrenci için de öğretmen odur. Her gün birçok fidana su veren öğretmenler, gelecekte dini, vatanı için yapraklarını yeşerten bir ağaç büyütürler (2. Sınıf, bayan).

Yağmur

Öğretmenlik mesleği gökyüzünden rahmet olarak yă̆an yă̆mura benzer. Çünkü ögretmen, her bir yağmur tanesinin çiçekleri açtırıp yeşertmesi gibi öğrencilerin kalplerinde çiçekler açtırıp onlara umut olurlar (2.sınıf, bayan).

Hayat

Öğretmenlik mesleği hayat gibidir. Çünkü hayatın farkl farkl yönlerini öğreten ögretmenler öğrencilerine yaşamayı öğretirler (2. Sinıf bayan).

Cemre

Öğretmenlik mesleği baharın gelişini haber veren cemreler gibidir. Çünkü ögrretmen ögrencinin gülüşüne düşen en güzel cemredir (2. Sinıf, bayan).

Nehir

Öğretmenlik mesleği nehir gibidir. Çünkü geçtiği yeri yeşertir (2. Sınıf bayan). 
Kategori 7. Yol Gösterici/Yönlendirici Öğretmen. Tablo 3' e göre bu kategori 22 aday öğretmen $(\%, 8,6)$ ve 13 metafor $(\% 12)$ ile temsil edilmektedir. Bu kategorideki metaforların en önemlileri şunlardır: Rehber (5 öğretmen adayı, \%1,9), ayna (3, \% $1,1)$, pusula $(3, \% 1,1)$, kutup yıldızı $(2, \% 0,7)$, navigasyon $(1, \% 0,3)$, Orkestra Şefi $(1, \% 0,3)$. Aşağıda, bu kategoride yer alan metaforlarla ilgili aday öğretmenlerin tanımlanmalarına ilişkin örnekler yer almaktadır.

Rehber

Öğretmenlik rehberlik gibidir. Çünkü hayatın başındaki yeni nesillere yol gösteren ögretmendir. Doğruyu yanlışı doğru kişiden öğrenen genç hayatta daha başarılı ve mutlu olacaktır (2. Sinıf, erkek).

Ayna

Öğretmenlik mesleği ayna gibidir/benzer. Çünkü ögretmen her öğrencisine farklı yaklaşarak onların zamanla kendi yansımalarını bulmalarına rehberlik eder( 3. Sinıf, bayan).

\section{Pusula}

Öğretmenlik mesleği pusulaya benzer. Çünkü Öğretmenler ülkemizin geleceğinin mimarları, rol modelleri ve yol göstericileridir (4. Sinıf, bayan).

Kutup y1ldiz1

Öğretmenlik mesleği kutup yıldızı gibidir/benzer. Çünkü yol bulmak isteyen ve kaybolmuş her ögrenci ona baktı̆̆ında, ona uyduğunda yönünü ve yolunu bulur (3. Sinif, erkek).

Navigasyon

Öğretmenlik mesleği navigasyon gibidir. Çünkü ĕgitim öğretim uzun ve önemli bir yoldur ögrenci için. Öğretmenler de bu yolda kllavuzdur. Bilgi deneyimiyle ögrenciye uygun donanımı paylaşarak öğrencinin bu yolda en iyiye ulaşmasına rehberlik eder (3. Sinif, bayan).

Orkestra şefi

Öğretmenlik mesleği orkestra şefine benzer. Çünkü şef orkestrayı ne ölçüde yönetir ve yol gösterirse o ölçüde başarll olacaktır. ögretmenler de orkestra şefi gibi ögrenciye liderlik ederler, yol gösterirler (4. Sinıf, erkek).

Kategori 8. Mutlu Eden/Eğlendiren Öğretmen. Tablo 3' e göre bu kategori 5 aday öğretmen $(\% 1,9)$ ve 5 metafor $(\% 4,6)$ ile temsil edilmektedir. Bu kategorideki metaforların en önemlileri şunlardır: Akıl oyunu (1, \% 0,3), hediye paketi $(1, \% 0,3)$, su doku bulmaca $(1, \% 0,3)$. Aşağıda, bu kategoride yer alan metaforlarla ilgili aday öğretmenlerin tanımlanmalarına ilişkin örnekler yer almaktadır. 


\section{Ak1l oyunu}

Öğretmenlik mesleği akıl oyunu gibidir. Çünkü akıl oyununu keyif veren tarafinı yani bulmacaya benzeyen o algısını çözdükçe, keyif alırız, becerilebildiğin takdirde oldukça keyif vericidir. Bu yüzden oyunu kurallarına yani püf noktalarına göre oynarsak vazgeçilemez eşsiz bir meslektir (3. Sınıf, bayan).

Hediye paketi

Öğretmenlik mesleği hediye paketi gibidir. Çünkü içinden ne çıkacă̆ı belli olmaz ama insana heyecan verir, mutlu eder. Inşallah herkesin karşısına onu mutlu edecek bir hediye çıkar (3. Sınıf, bayan).

Sudoku bulmaca

Öğretmenlik mesleği sudoku bulmaca gibidir. Çünkü ilk bakışta çok zor gibi görünse de çözmeye başladıkça zevkli ve keyifli bir hale gelir, başardıkça yapasın gelir. (3. Sinif, bayan).

Kategori 9. Problem Çözen Öğretmen. Tablo 3' e göre bu kategori 4 aday öğretmen $(\% 1,5)$ ve 4 metafor $(\% 3,7)$ ile temsil edilmektedir. Bu kategorideki metaforların en önemlileri şunlardır: Filozof (2, öğretmen adayı, \% 0,7), bulmaca çözmek ( $1, \%$ 0,3). Aşağıda, bu kategoride yer alan metaforlarla ilgili aday öğretmenlerin tanımlanmalarına ilişkin örnekler yer almaktadır.

\section{Filozof}

Öğretmenlik filozof olmaya benzer. Çünkü sadece dersle ilgili bilgi değil, hayatla ilgili bilgi de verilir. Öğrencilerin her alanda soruları ve sorunları çözülmeye çalışılır (4. Sinıf, bayan).

\section{Bulmaca çözmek}

Öğretmenlik mesleği bulmaca çözmeye benzer. Çünkü kafalardaki yıllarca oluşmuş o sorularl ancak sen çözersin. Ve bütün doğru cevaplar sadece sendedir (4. Sinif, bayan).

Kategori 10. Çok Yönlü Öğretmen. Tablo 3' e göre bu kategori 2 aday öğretmen $(\%$ 0,7) ve 2 metafor $(\%$ 1,8) ile temsil edilmektedir. Bu kategorideki metaforlar şunlardır: İsviçre çakısı (1, \% 0,3), matruşka (1, \% 0,3). Aşağıda, bu kategoride yer alan metaforlarla ilgili aday öğretmenlerin tanımlanmalarına ilişkin örnekler yer almaktadir.

\section{İsviçre çakısı}

Öğretmenlik mesleği Isviçre çakısı gibidir. Çünkü İsviçre çakısının bir tek işlevi yoktur. Bir çok işlevi vardır. Öğretmenin de tek yönlü değil, bir çok yönden işlevi vardır. İçinden ne çıkacă̆ını bilemezsiniz (4. Sınıf, bayan). 


\section{Matruşka}

Öğretmenlik mesleği matruşka gibidi/benzer. Çünkü açıldıkça derinliği ortaya çıkar. Bilgi arttıkça düşünce ve fikirde gelişme meydana gelir. Bu da ögrenciye yansır ve matruşkalar çoğalır (4. Sinıf, bayan).

Kategori 11. Zorluklarla Mücadele Eden Öğretmen. Tablo 3' e göre bu kategori 2 aday öğretmen $(\% 0,7)$ ve 2 metafor $(\% 1,8)$ ile temsil edilmektedir. Bu kategorideki metaforlar şunlardır: Topuklu ayakkabı (1, \% 0,3), pazarcı (1, \% 0,3). Aşağıda, bu kategoride yer alan metaforlarla ilgili aday öğretmenlerin tanımlanmalarına ilişkin örnekler yer almaktadır.

Topuklu ayakkab1

Öğretmenlik mesleği topuklu ayakkabıya benzer. Çünkü dışardan bakıldı̆̆ında güzel ve rahat görünür ama ayă̆ınıza verdiğ $i$ ăgrlyı, rahatsılı̆̆ $\breve{g}_{l}$ bir siz bilirsiniz. Ögretmenlikte aynı şekilde en rahat ve en güzel meslek gibi görünür, ama göründüğünden ibaret değildir çünkü zorluklarını da yaşayan ögrretmenlerdir (4. Sinif, bayan).

\section{Pazarc1}

Öğretmenlik mesleği pazarcı gibidir/benzer. Çünkü pazarcını pazarda her bir meyve ve sebzeyi satmaya çalışmasi gibi zor bir süreçte öğrenciye bilgi satmaya çalışır (4. Sinıf, erkek).

\section{Öğretmenler ile İlgili Bulgular}

\section{Araștırmaya katılan öğretmenlerle ilgili tanımlayıcı bilgiler}

Araştırmaya katılan öğretmenlerle ile ilgili tanımlayıcı bilgiler Tablo 4'te verilmiştir.

Tablo 4.

Araştırmaya Katılan Öğretmenlere Ait Tanımlayıcı Bilgiler

\begin{tabular}{lll}
\hline Değişken & Kategori & $\mathbf{N}$ \\
\hline \multirow{2}{*}{ Cinsiyet } & Bayan & 45 \\
& Erkek & 35 \\
\hline \multirow{3}{*}{ Yaş } & $20-27$ & 22 \\
& $28-35$ & 19 \\
& $36-42$ & 10 \\
& $43-49$ & 18 \\
& $50-58$ & 7 \\
\multirow{4}{*}{ Kidem } & $59-65$ & 4 \\
& $1-2$ & 15 \\
& $3-7$ & 23 \\
& $8-15$ & 16 \\
& $16-22$ & 10
\end{tabular}




\begin{tabular}{|c|c|c|}
\hline & $23-29$ & 9 \\
\hline & $30-38$ & 7 \\
\hline TOPLAM & & 80 \\
\hline
\end{tabular}

Araştırmaya 80 öğretmen katılmıştır. Tablo 4'e göre bunların 45'i bayan $(\% 56,25), 35$ 'i erkektir (\% 43,75). Öğretmenlerin yaşlarına baktığımızda; 22'si (\% 27,5) 22-27, 19 'u (\% 23,75) 28-35, 10 'u (\% 12,5) 36-42, 18 'i (\% 22,5) 43-49, 7'si (\% $8,75)$ 50-58, 4'ü (\% 5) 59-65 yaş aralığındadır. Öğretmenlerin kıdemlerine bakıldığında 15'i (\% 18,75) 1-2 y1llık öğretmendir. 23'ü (\% 28,75) 3-7, 16's1 (\% 20) 8-15, 10’u (\% 12,5) 16-22, 9'u (\% 11,25) 23-29, 7'si (\% 8,75) 30-38 yıllık öğretmendir.

\section{Öğretmenler tarafından üretilen metaforlar}

Araştırmaya katılan din öğretimi alan öğretmenleri “Öğretmenlik” kavramına ilişkin geliştirdikleri metaforlar ve onları temsil eden öğretmen sayısı ve yüzdesi (alfabetik sıraya göre) Tablo 5'te verilmiştir.

Tablo 5.

Öğretmenlerin “Öğretmenlik” Kavramına İlişkin Ürettikleri Metaforların Frekans Ve Yüzde Dă̆llımları

\begin{tabular}{|c|c|c|c|c|c|c|c|}
\hline $\begin{array}{l}\text { Metafor } \\
\text { Sirası }\end{array}$ & Metafor Adı & $\mathbf{N}$ & $\%$ & 23 & $\begin{array}{l}\text { Fidan } \\
\text { dikmek }\end{array}$ & 3 & 3,75 \\
\hline 1 & Ağaç & 8 & 10 & 24 & Güneş & 4 & 5 \\
\hline 2 & Aile & 1 & 1,25 & 25 & Gökkuşağ 1 & 1 & 1,25 \\
\hline 3 & Akıllı telefon & 1 & 1,25 & 26 & Gökyüzüne & 1 & 1,25 \\
\hline 4 & Anne & 2 & 2,5 & & uçmak & & \\
\hline 5 & Arkadaşlık & 1 & 1,25 & 27 & Hava & 1 & 1,25 \\
\hline 6 & Arkeolog & 1 & 1,25 & & olayları & & \\
\hline 7 & Aş1 & 1 & 1,25 & 28 & Hayat & 1 & 1,25 \\
\hline 8 & Ateş böceği & 1 & 1,25 & 29 & Heykeltıraş & 2 & 2,5 \\
\hline 9 & Bahçıvan & 11 & 13,75 & 30 & Huysuz & 1 & 1,25 \\
\hline 10 & Balık tutmak & 1 & 1,25 & & sevgili & & \\
\hline 11 & Baraj & 1 & 1,25 & 31 & Iş1k & 1 & 1,25 \\
\hline 12 & Başak & 1 & 1,25 & 32 & Kalem & 1 & 1,25 \\
\hline 13 & Bayrak & 1 & 1,25 & 33 & Kalp & 1 & 1,25 \\
\hline 14 & Bukalemun & 1 & 1,25 & 34 & Kutup y1ldizı & 1 & 1,25 \\
\hline \multirow[t]{2}{*}{15} & Büyük & 1 & 1,25 & 35 & Med cezir & 1 & 1,25 \\
\hline & kardeş & & & 36 & Mum & 3 & 3,75 \\
\hline 16 & Can eriği & 1 & 1,25 & 37 & Nakkaş & 1 & 1,25 \\
\hline 17 & Çiçek & 1 & 1,25 & 38 & Navigasyon & 1 & 1,25 \\
\hline \multirow[t]{2}{*}{18} & Çiçek & 2 & 2,5 & 39 & Orkestra şefi & 1 & 1,25 \\
\hline & yetiştirmek & & & 40 & Oyuncu & 1 & 1,25 \\
\hline 19 & Çiftçi & 1 & 1,25 & 41 & Pilot & 1 & 1,25 \\
\hline 20 & Çoban & 1 & 1,25 & 42 & Pusula & 1 & 1,25 \\
\hline 21 & Çeşme & 1 & 1,25 & 43 & Rol model & 1 & 1,25 \\
\hline \multirow[t]{2}{*}{22} & Doğa & 1 & 1,25 & 44 & Sanat & 1 & 1,25 \\
\hline & & & & 45 & Sanatkâr & 1 & 1,25 \\
\hline
\end{tabular}




\begin{tabular}{llll}
\hline 46 & Sihirbazlık & 1 & 1,25 \\
47 & Su & 2 & 2,5 \\
48 & Suyun & 1 & 1,25 \\
& kaynağ & & \\
49 & Trafik şeridi & 1 & 1,25 \\
50 & Toprak & 1 & 1,25 \\
\hline
\end{tabular}

\begin{tabular}{llll}
\hline 51 & $\begin{array}{l}\text { Tükenmez } \\
\text { kalem }\end{array}$ & 1 & 1,25 \\
52 & Yaşam & 1 & 1,25 \\
& & & \\
TOPLAM & & $\mathbf{8 0}$ & $\mathbf{1 0 0}$ \\
\hline
\end{tabular}

Tablo 5 incelendiğinde araştırma 80 öğretmen ile gerçekleştirilmiştir. Katılımcıların ürettikleri metaforlar ile ilgili bulguları aşağıdaki gibi özetleyebiliriz:

1. 80 öğretmen "öğretmenlik" kavramı ile ilgili olarak 52 adet metafor geliştirmiştir.

2. Öğretmenleri ürettiği 52 metaforun 43’ü sadece bir öğretmen tarafindan temsil edilmektedir. Bu da yaklaşık olarak katılımcıların \% 53,7'sine karşılık gelmektedir. Geriye kalan \% 46,3 öğretmen adayı 9 adet metafor üretmişlerdir. Başka bir ifadeyle 9 metafor 2 ila 11 öğretmen adayı arasında değişen rakamlarda temsil edilmektedir. Metafor başına düşen öğretmen sayısı ise 1,53'dür.

3. İlk beş sırada yer alan metaforlar şöyle belirlenmiştir: (1) Bahçıvan, 11 öğretmen, \% 13,7. (2) A ğaç, 8 öğretmen, \% 10. (3) Güneş, 4 öğretmen, \% 5. (4) Mum, 3 öğretmen, \% 3,75. (5) Fidan dikmek 3 öğretmen, \% 3,75.

4. 52 adet metaforun 22'si canlı varlıklarla, 30’u cansız varlıklarla ilgilidir. 22 canlı varlıkla ilgili metaforun 4'ü bitkilerle, 2'si hayvanlarla, 16'sı da insan ile ilgilidir. 16 adet insan ile ilgili metaforun 10 tanesi mesleklerle ilgilidir. Yani 10 metaforda öğretmenlik mesleği başka bir meslek ile ilişkilendirilerek anlatılmaya çalışılmıştır. 30 adet cansız metaforun 24'ü somut varlıklarla, 6'sı soyut varlıklarla ilişkilidir.

\section{Öğretmen adayları tarafından üretilen metaforların ait oldukları kategoriler}

Tablo 6.

\section{Metaforların Kategorilere Dă̆ılımı}

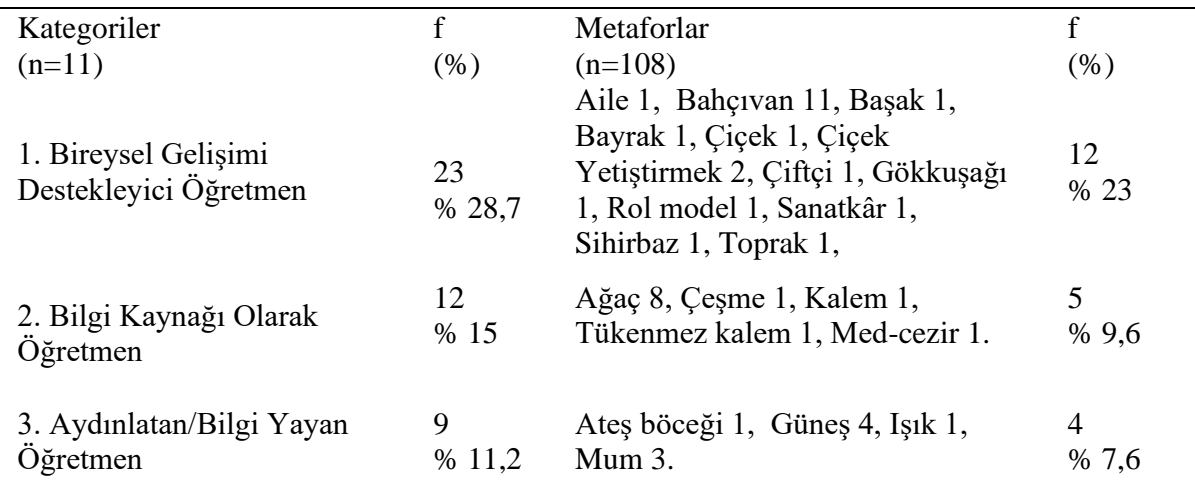




\begin{tabular}{|c|c|c|c|}
\hline $\begin{array}{l}\text { 4.Şekillendiren/Biçimlendiren } \\
\text { Öğretmen }\end{array}$ & $\begin{array}{l}9 \\
\% 11,2\end{array}$ & $\begin{array}{l}\text { Arkadaşlık 1, Arkeolog 1, Fidan } \\
\text { dikmek } 3 \text {, Heykeltıraş 2, Nakkaş 1, } \\
\text { Sanat } 1 .\end{array}$ & $\begin{array}{l}6 \\
\% 11,5\end{array}$ \\
\hline $\begin{array}{l}\text { 5. Yol Gösterici/Yönlendirici } \\
\text { Ögrretmen }\end{array}$ & $\begin{array}{l}8 \\
\% 10\end{array}$ & $\begin{array}{l}\text { Ak1lli telefon 1, Çoban 1, Kutup } \\
\text { Y1ldızı 1, Navigasyon 1, Pilot 1, } \\
\text { Pusula 1, Orkestra Şefi 1, Yaşam } 1 .\end{array}$ & $\begin{array}{l}8 \\
\% 15,3\end{array}$ \\
\hline $\begin{array}{l}\text { 6. Koruyucu/İdareci } \\
\text { Öğretmen }\end{array}$ & $\begin{array}{l}6 \\
\% 7,5\end{array}$ & $\begin{array}{l}\text { Anne 2, Aş1 1, Baraj 1, Büyük } \\
\text { kardeş 1, Trafik şeridi } 1 .\end{array}$ & $\begin{array}{l}5 \\
\% 9,6\end{array}$ \\
\hline $\begin{array}{l}\text { 7. Yaşam Kaynă̆ } / \text { Umut } \\
\text { Olarak Öğretmen } \\
\text { 8. Mutlu Eden/Eğlendiren } \\
\text { Öğretmen }\end{array}$ & $\begin{array}{l}5 \\
\% 6,2 \\
3 \\
\% 3,7\end{array}$ & $\begin{array}{l}\text { Hayat 1, Kalp 1, Su 2, Su kaynağ } 1 \\
1 . \\
\text { Huysuz sevgili 1, Gökyüzüne } \\
\text { uçmak 1, Oyuncu } 1 .\end{array}$ & $\begin{array}{l}4 \\
\% 7,6 \\
3 \\
\% 5,7\end{array}$ \\
\hline 9. Çok Yönlü Öğretmen & $\begin{array}{l}2 \\
\% 2,5\end{array}$ & Bukalemun 1, Hava olayları 1. & $\begin{array}{l}2 \\
\% 3,8\end{array}$ \\
\hline 10. Fedakâr Öğretmen & $\begin{array}{l}2 \\
\% 2,5\end{array}$ & Balık tutmak 1, Doğa 1. & $\begin{array}{l}2 \\
\% 3,8\end{array}$ \\
\hline $\begin{array}{l}\text { 11. Zorluklarla Mücadele } \\
\text { Eden Öğretmen }\end{array}$ & $\begin{array}{l}1 \\
\% 1,2 \\
\end{array}$ & Can eriği 1 & $\begin{array}{l}1 \\
\% 1,9 \\
\end{array}$ \\
\hline
\end{tabular}

\section{Sonuç ve Öneriler}

$\mathrm{Bu}$ araştırmanın amacı din öğretiminde aday öğretmenler ile öğretmenlerin "öğretmenlik" ile ilgili metaforik algılarını belirlemek, bu metafor imgelerini bazı kavramsal kategoriler altında toplamak ve aday öğretmenler ile öğretmenlerin öğretmenlik mesleği ile ilgili zihinsel imgelerini birbirleri ile ilişkilendirmek olarak belirlenmişti. $\mathrm{Bu}$ amaçla 255 aday öğretmen ve 80 öğretmenden yarı yapılandırılmış form aracılığıyla öğretmenlik mesleği ile ilgili metaforlar geliştirmeleri istenmiştir. Sonuçta aday öğretmenler öğretmenlik mesleğini 108 farklı metafor üzerinden, öğretmenler 52 farklı metafor üzerinden açıklanmıştır. Bu durum her iki katılımcı grup (hem aday öğretmenler hem de öğretmenler) tarafindan öğretmenlik mesleğinin geniş bir metaforik algı ile algılandığını göstermektedir. Aday öğretmenler ile öğretmenler öğretmenlik mesleğini tanımlarken 21 ortak metafor kullanmışlardır. Bu metaforlar; ă̆aç, aile, anne, bahçıvan, çiçek, çiçek yetiştirmek, çiftçi, güneş, gökkuşă̆l, hayat, ışık, kalem, kutup yıldızı, mum, nakkaş, navigasyon, orkestra şefi, pusula, sanatkâr, su ve toprak olarak belirlenmiştir. Bu durum din eğitimcileri olarak hem aday öğretmenler hem de öğretmenlerin, öğretmenlik mesleği ile ilgili ortak algılara sahip olduklarını göstermektedir.

Aday öğretmenlerin ürettikleri ilk beş metafor; "anne (21), güneş (17), bahçıvan (14), mum (13) ve aile (9)", öğretmenlerin ürettikleri ilk beş metafor; "bahçıvan (11), ağaç (8), güneş (4), mum (3) ve fidan dikmek (3)" olarak belirlenmiştir. Burada da 3 metaforun (bahçıvan, güneş, mum) ortak olduğu görülmektedir. Saban (2004) tarafından yapılan ve 54 metaforun üretildiği araştırmada ilk 5 sırada yer alan metaforlar; "bahçıvan (12), su (11), güneş (9), heykeltıraş (9) ve çiftçi (8)" olarak 
tespit edilmiştir. İki araştırmada ilk beş metafor içerisinde iki metaforun (bahçıvan, güneş) ortak olması dikkat çekicidir. Yılmaz, Göçen, Yılmaz'ın (2013) araştırmasında da "anne-baba (34), bahçıvan (23), anne (21), rehber (21), aile (14)" en çok tespit edilen 5 metafordur. $\mathrm{Bu}$ araştırma ile Yılmaz, Göçen ve Yılmaz'ın (2013) araştırmasını karşılaştırdığımızda benzer bir şekilde ilk beş metafor içerisinde "bahçıvan, anne ve aile" metaforları ortaktır. Koç'un (2014) araştırmasında da benzer bir şekilde ilk 5 metafor güneş (21), 1şık (14), mum (12), ebeveyn (11) ve ağaç (11) olarak tespit edilmiştir. Burada da "güneş, mum, ebeveyn (aile) ve ağaç metaforlarının ortak olduğu görülmektedir. $\mathrm{Bu}$ da öğretmenlik algısı, aday öğretmenler ve öğretmenlerin öğretmenliği tanımlarken kullandıkları metaforlar açısından bu araştırma ile Saban (2004), Yılmaz, Göçen ve Yılmaz'ın (2013) ve Koç'un (2014) bulgularının örtüştüğünü göstermektedir. $\mathrm{Bu}$ bağlamda aday öğretmenler ve öğretmenler tarafından öğretmenlik tanımlanırken en çok kullanılan güneş, mum gibi imgeler, öğretmenliğin insanlığı aydınlatan, bilgi yayan, insanları cehalet karanlığından aydınlığa ulaştıran bir ışık olarak görüldüğü için kullanılmaktadırlar. Anne ve aile imgeleri insanların ilk öğretmenleri aileleri ya da anneleri olduğu için zihinsel işlemlerde öğretmenlik aile ya da anne ile ilişkilendirilerek açıklanmaktadır. Aynı zamanda bu araştırma göstermiştir ki, anne imgesinin bireyler üzerindeki koruyucu, idareci rolü öğretmen için de düşünülmekte ve öğretmenler de anneler gibi bireyleri koruyan, kollayan bir figür olarak görülmektedirler. Bahçıvan metaforuna gelince, aday öğretmen ve öğretmenler öğretmenliğin insanlığın bireysel gelişimine yöne verici, birey ve toplum inşasında aynı özenle bir bitki yetiştiricisi olarak bahçıvan gibi öğretmenlerin bireyleri, nesilleri ve geleceği inşa ettiklerini vurgulamaktadırlar. Ağaç metaforunda da öğretmen bilgi kaynağı olarak ifade edilmiş, ağacın meyve vermesi gibi öğretmenlerin bireylere bilgi kaynaklığı yaptığı vurgulanmıştır.

Aday öğretmenlerin ürettikleri metaforlar 11 kavramsal kategoride toplanmıştır (Tablo 3). Öğretmenlerin ürettikleri metaforlar da 11 farklı kavramsal kategoride toplanmıştır (Tablo 6). Yani aday öğretmenler ve öğretmenler öğretmenliği tanımlarken çok benzer ifadeler kullanmışlardır. Araştırma bulguların göre, aday öğretmenlerin \%24,7'si aydınlatıcı/bilgi yayıc1, \%19,2'si bireysel gelişimi destekleyici, \%12,9'u koruyucu/idareci, \%10,5'i bilgi kaynağ1, \%9,8'i şekillendirici/biçimlendirici, \%9'u yaşam kaynağı/umut, 58,6's1 yol gösteren/yönlendiren, \%1,9'u mutlu eden/eğlendiren, \%1,5'i problem çözen, \%0,7'si çok yönlü ve $\% 0,7$ 'si de zorluklarla mücadele eden öğretmen olarak tanımlanmışlardır. Buna göre aday öğretmenler öğretmenliği en fazla aydınlatan, bilgi yayan olarak tanımlamaktadırlar. Araştırma bulgularına göre öğretmenler de benzer tanımlamalar yapmışlardır. Öğretmenlerin \%28,7'si bireysel gelişimi destekleyici, \%15'i bilgi kaynağ1, \%11,2'si aydınlatan/bilgi yayan, \%11,2'si şekillendiren/biçimlendiren, \%10'u yol gösteren/yönlendiren, \%7,5'i koruyan/idare eden, \%6,2'si yaşam kaynağ1/umut, \%3,7'si mutlu eden/eğlendiren, \%2,5'i çok yönlü, \%2,5'i de fedakâr öğretmen olarak tanımlamışlardır. Buna göre öğretmenler öğretmenliği en fazla bireysel gelişimi destekleyen olarak tanımlamaktadırlar. $\mathrm{Bu}$ 
sonuçlara göre hem aday öğretmenlerin hem de öğretmenlerin öğretmenlik tanımlamaları birbirine çok benzemektedir. Aday öğretmenler ile öğretmenler arasındaki tek fark, aday öğretmenlerin kategorilerindeki problem çözen öğretmen tanımlamasının yerini öğretmenlerin kategorilerinde fedakâr öğretmenin almasıdır. Saban'ın (2004) araştırmasında metaforlar 6 farklı kategoride toplanmıştır. Bunlar; \% 32, 3'ü bilgi sağlayıcı, \%30,3'ü şekillendirici ve biçimlendirici, \% 1,4'ü tedavi edici, \% 1,3'ü eğlendirici, \% 21,2'si bireysel gelişimi destekleyici, \% 13,5'i de yol gösterici ve yönlendirici öğretmen kategorileri altında yer almaktadır. Buna göre her iki araştırmada elde edilen bulgular birbirleriyle örtüşmektedir. Şöyle ki; Saban'ın (2004) oluşturduğu kategoriler ile bu araştırmada oluşturulan kategorilerin 5'i ortaktır. Bu kategoriler; bilgi kaynağı, şekillendiren ve biçimlendiren, bireysel gelişimi destekleyen, yol gösteren ve eğlendiren öğretmen kategorileridir. Yılmaz, Göçen ve Yılmaz'ın (2013) araştırmasında metaforlar 7 kategori altında toplanmıştır. Öğretmen adaylarının oluşturdukları metaforların \%31,62'si şekillendirici öğretmen, \%31,62'si yol gösterici öğretmen, \%15,41'i bilgi kaynağ1 olan öğretmen, \%6,76’s1 statüsü olmayan öğretmen, \%5,41'i esnek öğretmen, \%5,41'i model olan öğretmen ve \%3,78'i de kutsal bir iş yapan öğretmen kategorileri altında yer almaktadır. Buna göre her iki araştırmada elde edilen bulgular arasında benzerlik vardır. Şöyle ki; şekillendirici, yol gösterici ve bilgi kaynağı olan öğretmen kategorileri ortaktır. Koç'un (2014) araştırmasında metaforlar 8 kategori altında toplanmıştır. Bunlar; bilgi kaynağ1, motivasyon kaynağ1, yol gösterici, fedakârlık örneği, yetiştirici ve geliştirici, lider, kişisel gelişim kaynağı, tedavi edici ve iyileştirici olarak öğretmen kategorileridir. Buna göre her iki araştırmada elde edilen bulgular birbirleriyle örtüşmektedir. Şöyle ki; bilgi kaynağ1, yol gösterici, fedakâr, kişisel gelişim kaynağı kategorileri ortak bulgular arasındadır. Bununla birlikte sadece bu araştırmaya özgü kategoriler de vardır. Örneğin koruyucu/idareci, yaşam kaynağı/umut olarak, problem çözen, çok yönlü, zorluklarla mücadele eden öğretmen kategorileri gibi.

Literatüre bakıldığında bu amaçla yola çıkan ve metaforik algı analizi yapmaya çalışan pek çok araştırma genellikle ya aday öğretmenlerle, ya öğrencilerle ya da öğretmenlerle yapılmıştır. Bu araştırma ise din öğretimi alanında aday öğretmenler ve öğretmenlerle yapılmış ve her iki grup arasında bir karşılaştırma yapma imkânı ortaya koymuştur. Bu da bu araştırmayı diğerlerinden farklı kılmaktadır.

Araştırma sonuçlarına göre şu öneriler geliştirilmiştir:

1. Araştırma bulgularına göre öğretmenlik tanımlanırken en çok kullanılan metaforlar düşünüldüğünde din öğretiminde hem aday öğretmenler hem de öğretmenler için öğretmenlik, insanlığ 1 aydınlatan, bilgiye kaynaklık eden, bilgi yayan, bireysel gelişimi saylayan, insanları şekillendiren, onlara yol gösteren olarak ifade edilmiştir. Bu bağlamda din öğretimi alan temsilcisi olan öğretmenler için kaliteli bir hizmet öncesi eğitim bağlamında İslami İlimler ve İlahiyat Fakültelerinde bu özelliklere sahip nitelikli temsilciler yetiştirilmesine azami özen gösterilmesi önerilebilir. 
2. Din öğretiminde insanlığı aydınlatan, bilgiye kaynaklık eden, bilgi yayan, bireysel gelişimi saylayan, insanları şekillendiren, onlara yol gösteren öğretmenlerin yetişebilmesi için hizmet öncesi eğitimde özellikle pedagojik formasyon alanı derslerinde yetişen bireylerin ihtiyaçlarının azami oranda karşılanabilmesi için yapılması gerekenler üzerine düşünülmesi önerilebilir.

3. Bu araştırma bulgularının din öğretiminde öğretmen yetiştiren fakültelerdeki pedagojik formasyonla ilgili derslerde kullanılmasının sağlanması ve yetişen aday öğretmenlerin öğretmenlik rolleri ya da kendi öğretmen kimliklerini geliştirirken sahip olmaları gereken nitelikler üzerine düşünmelerinin sağlanması önerilebilir.

4. Din öğretiminde yukarıda ifade edilen insanlığg aydınlatan, bilgiye kaynaklık eden, bilgi yayan, bireysel gelişimi saylayan vb. gibi nitelikli ve kaliteli bir öğretmenlik yapılabilmesi için aday öğretmenlere etkili öğretmenlik becerilerine dönük teorik bilgilerle birlikte uygulama içeren faaliyetlere daha fazla yer verilmesi önerilebilir. Bu bağlamda öğretmenlik uygulaması ve okul deneyimi gibi derslerin daha etkili bir şekilde kullanılmaları önerilebilir.

5. Din Öğretiminde aday öğretmenler için etkili öğretmenlik bilgi ve becerileri anlamında ögretim yöntem ve teknikleri bağlamında yukarıda ifade edilen nitelikli ve kaliteli öğretmenliği yapabilmeleri için daha fazla çağdaş yöntem ve tekniklerden faydalanmaları, yapılandırmacı ve zengin etkileşimli sınıf ortamlarını yaratabilmelerine dönük şekilde yetiştirilmelerinin sağlanması önerilebilir. Aynı şekilde; öğretim teknolojileri ve materyal tasarım, sınıf yönetimi, ölçme ve değerlendirme vb. gibi alanlarda da etkili öğretmenlik bilgi ve becerisine sahip olarak yetiştirilmelerinin sağlanması önerilebilir.

6. Din öğretiminde insanlığı aydınlatan, bilgiye kaynaklık eden, bilgi yayan, bireysel gelişimi sağlayan vb. gibi nitelikli ve kaliteli bir öğretmenlik yapılabilmesi için öğretmenlerin etkili öğretmenlik becerilerine dönük teorik bilgilerle birlikte uygulama içeren faaliyetlerle hizmet içi eğitimlerine devam edilmesi önerilebilir. Bu eğitimlerin seminer ya da konferans şeklinde değil, küçük gruplar ile uygulama ya da etkinlik şeklinde yürütülmesi ve bu eğitimlerin araştırma bulgularının tanımladığı öğretmen rolleri ile ilişkisinin kurularak gerçekleştirilmesi önerilebilir.

7. Bireysel algıların ortaya konabilmesi ve bu zihinsel imgeler üzerinden algıların kategorize edilmesi ihtiyacının karşılanması amacıyla bir araç olarak metaforlar kullanılabilmektedir. $\mathrm{Bu}$ bağlamda aday öğretmenler ve öğretmenler ile hem din öğretiminde hem de diğer alanlarda metaforik analizler içeren benzer araştırmaların yapılması ve bu şekilde alana katkı sunulması önerilebilir.

8. Metaforlar üzerinden analiz içeren benzer araştırmaların eğitim-öğretim ile ilgili diğer paydaşların katlımı ile (öğrenci, yönetici, veli vb.) yapılması ve bu 
sayede öğretmen ve öğretmenlikle ilgili farklı bakış açılarının ortaya konulması önerilebilir.

\section{Çıkar Çatışması ve Etik Bildirimi}

Araştırma için gerekli etik kurul onayının Afyon Kocatepe Üniversitesi Sosyal ve Beşeri Bilimler Etik Kurulunun 27.04.2020 tarihli 2020/3 numaralı toplantı ve 2020/71 nolu karar ile alındığını, araştırmanın tüm süreçlerinde etik kurallara uyulduğunu beyan ederim.

\section{Kaynakça}

Alan, Y. (1994). Lisan ve insan. TÖV Yayınları.

Arslan, M. M., \& Bayrakçı, M. (2006). Metaforik düşünme ve öğrenme yaklaşımının eğitimöğretim açısından incelenmesi. Milli Eğitim Dergisi, 171, 100-108.

Aydın, İ. H. (2006). Bir felsefi metafor yolda olmak. Dinbilimleri Akademik Araştırma Dergisi, 6(1), 9-22.

Aykaç, N., \& Çelik, Ö. (2014). Öğretmenlerin ve öğretmen adaylarının eğitim programına ilişkin metaforik algılarının karşılaştııılması. Eğitim ve Bilim, 39(173), 328-340.

Baker, P.J. (1991). Metaphors of mindful engagement and a vision of beter schools. Educational Leadership. 48(6), 32-35.

Balc1, A. (1999). Metaphorical images of school: School perceptions of students, teachers and parents from four selected schools (in Ankara) (Tez No. 82164) [Doktora Tezi, Orta Doğu Teknik Üniversitesi-Ankara]. Yükseköğretim Kurumu Başkanlığı Ulusal Tez Merkezi.

Büyükkaragöz, S. S., Muşta, M. C., Y1lmaz, H., \& Pilten, Ö. (1998). Öğretmenlik mesleğine girişs (Ĕ̈itimin temelleri). Mikro Yayınları.

Cerit, Y. (2008). Öğretmen kavramı ile ilgili metaforlara ilişkin öğrenci, öğretmen ve yöneticilerin görüşleri. Türk Eğitim Bilimleri Dergisi, 6(4), 693-712.

Creswell, J. W. (2017). Araştırma deseni: Nicel, nitel ve karma yöntem yaklaşımı (3. baskı). (S. B. Demir, Çev.). Eğiten Kitap Yayınları.

Çakmak, F. (2013). Din kültürü ve ahlak bilgisi dersinde veli beklentileri. İlahiyat yayınları.

Çekmez, E., Yıldız, C., \& Bütüner, S. Ö. (2012). Fenomenografik araştırma yöntemi. Necatibey Eğitim Fakültesi Elektronik Fen ve Matematik Eğitimi Dergisi (Efmed), 6(2), 77-102.

Demirel, Ö. (1999). Planlamadan değerlendirmeye öğretme sanatı. Pegem Akademi.

Demirel, Ö., \& Kaya, Z. (2007). Eğitim bilimine giriş. Pegem Akademi.

Demirel, Ö. (2015). Eğitimde program geliştirme (23. bask1). Pegem Akademi. 
Egüz, Ş., \& Öntaş, T. (2018). Ortaokul öğrencilerinin "öğretmen” kavramına ilişkin kullandıkları metaforlar. MSKU Eğitim Fakültesi Dergisi, 5(1), 79-91. https://doi.org/10.21666/muefd.336181

Erden, M. (1998). Öğretmenlik mesleğine giriş. Alkım Yayınevi.

Ertürk, S. (1997). Eğitimde program geliştirme. Meteksan A.Ş.

Fidan, N. (1996). Öğrenme ve ögrretme. Alkım Yayınevi.

Kaya, Z. (2012). Gelişim ve ögrenme. Zeki Kaya (Ed.), Öğrenme ve Öğretme. (1. bask1, ss. 127) içinde. Pegem Akademi.

Kesici, A. E. (2016). Eğitimin temel kavramlart. Ayşe Elitok Kesici (Ed.) Eğitim Bilimine Giriş. (1. baskı, ss. 1-20) içinde. Eğiten Kitap Yayınları.

Kılıç, A., \& Saruhan H. (2005). Teknik eğitim fakültesi öğretmen adaylarının öğretmenlik becerileri. Marmara Üniversitesi MTET 2005 Kongresi Bildiriler Kitabı, 407-417.

Koç, E. S. (2014). Sınıf öğretmeni adaylarının öğretmen ve öğretmenlik mesleği kavramlarına ilişkin metaforik algıları. İnönü Üniversitesi Eğitim Fakültesi Dergisi, 15 (1), 47-72. https://doi.org/10.17679/iuefd.79408

Küçüktepe, S. E., \& Gürültü, E. (2014). Öğretmenlerin yapılandırmacı öğretmen kavramına ilişkin algılarına yönelik metafor çalışması örneği. Abant İzzet Baysal Üniversitesi Eğitim Fakültesi Dergisi, 14(2), 282-305. https://doi.org/10.17240/aibuefd.2014.14.25000091540

Lakoff, G., \& Johnson, M. (2010). Metaforlar: Hayat anlam ve dil. (G. Y. Demir, Çev.). Paradigma Yayınları.

Levine, P. M. (2005). Metaphors and images of classrooms. Kappa Delta Pi Record, 41(4), 172-175.

Martinez, M. A., Saulea, N., \& Huber, G. L. (2001). Metaphors as blueprints of thinking about teaching and learning. Teaching and Teacher Education, 17, 965-977.

Morgan, G. (1998). Yönetim ve örgüt teorilerinde metafor. (G. Bulut, Çev.). BZD Yayıncılık.

Nalçacı, A., \& Bektaş, F. (2012). Öğretmen adaylarının okul kavramına ilişkin algıları. Ahi Evran Üniversitesi Kırşehir Eğitim Fakültesi Dergisi (KEFAD), 13(1), 239-258.

Saban, A. (2004). Giriş düzeyindeki sınıf öğretmeni adaylarının “öğretmen” kavramına ilişkin ileri sürdükleri metaforlar. Türk Eğitim Bilimleri Dergisi, 2(2), 131-155.

Saban, A. (2008). İlköğretim I. kademe öğretmen ve öğrencilerinin bilgi kavramına ilişkin sahip oldukları zihinsel imgeler. Illköğretim Online, 7(2), 421-455. Erişim adresi: http://ilkogretim-online.org.tr/ 
Senemoğlu, N., Gömleksiz, M., \& Üstündağ, T. (2001). Öğrenmenin oluşumu öğretme model ve stratejileri. MEB Yayınları.

Şahin, A. (2011). Öğretmen algılarına göre etkili öğretmen davranışları. Ahi Evran Üniversitesi Eğitim Fakültesi Dergisi, 12(1), 239-259.

Şen, H. Ş., \& Erişen, Y. (2002). Öğretmen yetiştiren kurumlarda öğretim elemanlarının etkili öğretmenlik özellikleri. G.Ü. Gazi Ĕ̆itim Fakültesi Dergisi, 22(1), 99-116.

Şişman, M. (2016). Türk eğitim sistemi ve okul yönetimi (10. bask1). Pegem Akademi.

Özden, Y. (1999). Eğitimde dönüşüm eğitimde yeni değerler. Pegem Akademi.

Türk Dil Kurumu. (2020). www.tdk.gov.tr. Erişim Tarihi: 16.03.2020.

Tortop, H. S. (2013). Öğretmen adaylarının üniversite hocası hakkındaki metaforları ve bir değerlendirme aracı olarak metafor. Yükseköğretim ve Bilim Dergisi/Journal of Higher Education and Science, 3(2), 153-160. https://doi.org/10.5961/jhes.2013.070

Tosun C. (2001). Din ěgitimi bilimine giriş. Pegem Akademi

Varış, F. (1994). Eğitimde program geliştirme: Teori ve teknikler. Alkım Yayınları.

Yıldırım, A., \& Şimşek, H. (2013). Soysal bilimlerde nitel araştırma yöntemleri (8. baskı). Seçkin Yayıncılık.

Yılmaz, F, Göçen, S., \& Yılmaz, F. (2013). Öğretmen adaylarının öğretmen kavramına ilişkin algıları: Bir metaforik çalışma. Mersin Üniversitesi Eğitim Fakültesi Dergisi, 9(1), 151164. https://doi.org/10.17860/efd.49273

Yob, I. M. (2003). Thinking constructively with metaphors. Studies in Philosophy and Education, 22, 127-138.

\section{Extended Abstract}

People have shared their feelings, thoughts and ideas by using different ways from the moment they appeared on the stage of being. Education is a system of planned activities that provide certain improvements in people's behavior according to predetermined principles (Demirel \& Kaya, 2007). Learning is defined as behavioral change, which is a product of life and with a relatively permanent track (Ertürk, 1997). Accordingly, the fact that the purpose of education has been realized also means that learning has been realized (Kesici, 2016). Teaching is, in general terms, the task of guiding the learning task and performing it by a leader / teacher (Demirel, 2015). The teacher is the person who leads and guides the learning activity as an expert. In schools, which is a living space and where the educational activity takes place, it is an important need to improve the human power in schools in order to provide the desired quality of service. Religious education is defined as the process of attempting to intentionally make a desired change in the religious behavior of the individual through 
his own experiences (Tosun, 2001). In this context, Religious Culture and Moral Knowledge course is among the compulsory courses in our country. In addition, students can take Quran, Life of Muhammad and Basic Religious Knowledge as elective courses. It will be possible to meet the religious education needs of the educated people with a qualified teacher. In this context, the research examines the following problem: What are the metaphorical perceptions of religious education candidate teachers and teachers about "teaching"?

In this study, a phenomenological research pattern, one of the qualitative research patterns, was used. Phenomenological research is a research pattern in which the researcher describes the experiences of individuals related to a phenomenon defined by the participants (Creswell, 2017). This pattern focuses on facts that individuals are aware of but do not have an in-depth and detailed understanding of, such as events, perceptions, experiences, concepts and situations (Yıldırım and Şimşek, 2013). The research participants consisted of 255 candidate teachers studying at the Faculty of Islamic Sciences and 80 religious education teachers. In the research, metaphors were used as data collection tool. For this purpose, prospective teachers and teachers who form the study group of the research were asked to complete by giving forms that written "The teacher is like... / similar; because...". The data obtained in this study were analyzed using frequency, percentage calculations and content analysis method. Metaphor means a word used in a sense other than its real meaning as a result of interest or analogy. On the other hand, metaphor means using a word or concept to other meanings than accepted (TDK, 2020). Accordingly, metaphors are mental models that enable people to see a certain phenomenon with another phenomenon (Saban, 2008). There are metaphorical studies in the literature on concepts such as teacher, student, learning, teaching, school, program etc. (Baker, 1991; Balc1, 1999; Martinez, Sauleda \& Huber, 2001; Saban, 2004; Cerit, 2008; Nalçacı \& Bektaş, 2012; Tortop, 2013; Karateke, 2019).

According to the research findings, 255 prospective teachers developed 108 metaphors about teaching. The metaphors in the top five are as follows: (1) Mother, (2) Sun, (3) Gardener, (4) Candle, (5) Family. 42 of 108 metaphors are about living beings and 66 are about inanimate beings. Of the 42 living things, 10 metaphors are related to plants, 2 to animals and 30 to humans. 26 of 30 human metaphors are related to professions. In other words, in 26 metaphors, teaching was tried to be explained by associating with another profession. Of the 66 inanimate metaphors, 52 are related to concrete assets and 14 to abstract assets. Metaphors produced by prospective teachers were collected in 11 different categories. These categories are; teacher as enlightening / informing, supporting individual development, protective / managing, source of knowledge, shaping / shaping, source of life / hope, guiding / guiding, making / entertaining, problem solving, versatile, struggling with difficulties. 80 teachers who participated in the research developed 52 metaphors about teaching. The metaphors in the top five rank are as follows: (1) Gardener, (2) Tree, (3) Sun, (4) Candle, (5) Planting saplings. 22 of the 52 metaphors are related to living beings and 30 are related 
to inanimate beings. 4 of the 22 metaphors about living things are related to plants, 2 to animals and 16 to human. 10 of the 16 human metaphors are related to the professions. In other words, teaching in 10 metaphors is tried to be explained by associating with another profession. 24 of the 30 inanimate metaphors are related to concrete assets and 6 to abstract assets. Metaphors produced by teachers are collected in 11 different categories. These categories are teachers who supporting individual development, are the source of information, illuminate / radiate knowledge, shape / shape, guide / guide, protect / manage, source of life / hope, happy / entertaining, versatile, self-sacrificing teacher.

As a result, the metaphors produced by prospective teachers and teachers point to a broad perception of the teaching profession. The most commonly used images such as sun and candle are used when defining teaching, since teaching is seen as a light that illuminates humanity, radiates knowledge, and brings people from the darkness of ignorance to light. The protective and managerial role of the mother image on individuals is also considered for the teacher. The participants emphasize that teachers, like the gardener, are building individuals and the future. In the tree metaphor, the teacher was expressed as a source of information, and it was emphasized that teachers, like the fruit of the tree, give information to individuals. According to the results of the research, teachers' perceptions of prospective teachers and teachers are very close to each other. Metaphors of both prospective teachers and teachers were collected in 11 categories. These categories are also very close to each other. In addition, the findings of the research have been associated with similar research in the literature, and the results are found to be similar. 